\title{
Initial Concepts on Energetics and Mass Releases During Nonnuclear Explosive Events in Fuel Cycle Facilities

\section{DO NOI MICPOFILM COVER}

Prepared by M. A. Halverson, J. Mishima

Pacific Northwest Laboratory Operated by

Battelle Memorial Institute

Prepared for

U.S. Nuclear Regulatory

Commission 


\section{NOTICE}

This report was prepared as an account of work sponsored by an agency of the United States Government. Neither the United States Government nor any agency thereof, or any of their employees, makes any warranty, expressed or implied, or assumes any legal liability of responsibility for any third party's use, or the results of such use, of any information, apparatus, product or process disclosed in this report, or represents that its use by such third party would not infringe privately owned rights.

\section{NOTICE}

Availability of Reference Materials Cited in NRC Publications

Most documents cited in NRC publications will be available from one of the following sources:

1. The NRC Public Document Room, 1717 H Street, N.W. Washington, DC 20555

2. The Superintendent of Documents, U.S. Government Printing Office, Post Office Box 37082 , Washington, DC 20013-7082

3. The National Technical Information Service, Springfield, VA 22161

Although the listing that follows represents the majority of documents cited in NRC publications, it is not intended to be exhaustive.

Referenced documents available for inspection and copying for a fee from the NRC Public Docu ment Room include NRC correspondence and internal NRC memoranda; NRC Office of Inspection and Enforcement bulletins, circulars, information notices, inspection and investigation notices; Licensee Event Reports; vendor reports and correspondence; Commission papers; and applicant and licensee documents and correspondence.

The following documents in the NUREG series are available for purchase from the GPO Sales Program: formal NRC staff and contractor reports, NRC-sponsored conference proceedings, and NRC booklets and brochures. Also available are Regulatory Guides, NRC regulations in the Code of Federal Regulations, and Nuclear Regulatory Commission Issuances.

Documents available from the National Technical Information Service include NUREG series reports and technical reports prepared by other federal agencies and reports prepared by the Atomic Energy Commission, forerunner agency to the Nuclear Regulatory Commission.

Documents available from public and special technical libraries include all open literature items, such as books, journal and periodical articles, and transactions. Federal Register notices, federal and state legislation, and congressional reports can usually be obtained from these libraries.

Documents such as theses, dissertations, foreign reports and translations, and non-NRC conference proceedings are available for purchase from the organization sponsoring the publication cited.

Single copies of NRC draft reports are available free, to the extent of supply, upon written request to the Division of Technical Information and Document Control, U.S. Nuclear Regulatory Commission, Washington, DC 20555.

Copies of industry codes and standards used in a substantive manner in the NRC regulatory process are maintained at the NRC Library, 7920 Norfolk Avenue, Bethesda, Maryland, and are available there for reference use by the public. Codes and standards are usually copyrighted and may be purchased from the originating organization or, if they are American National Standards, from the American National Standards Institute, 1430 Broadway, New York, NY 10018. 


\section{Initial Concepts on Energetics and Mass Releases During Nonnuclear Explosive Events in Fuel Cycle Facilities}

Manuscript Completed: August 1986

Date Published: September 1986

Prepared by

M. A. Halverson, J. Mishima

Pacific Northwest Laboratory

Richland, WA 99352

\section{Prepared for}

Division of Fuel Cycle and Material Safety

Office of Nuclear Material Safety and Safeguards

U.S. Nuclear Regulatory Commission

Washington, DC 20555

NRC FIN B2481

\section{DISCLAIMER}

account of work sponsored by an agency of the United States States Government nor any agency thereof, nor any of their Government. Neither the United States or implied, or assumes any legal liability or responsiemployees, makes any warranty, express or implied, of any information, apparatus, product, or bility for the accuracy, completeness, or usefuld process disclosed, or represents that its use would nocess, or service by trade name, trademark, stitute or imply its endorsement, recommanufacturer, or otherwise does not necessarily constitute or any agency thereof. The views mendation, or favoring by the United States Governserily state or reflect those of the and opinions of authors expressed herein do nof

United States Government or any agency thereof. 


\section{DISCLAIMER}

This report was prepared as an account of work sponsored by an agency of the United States Government. Neither the United States Government nor any agency Thereof, nor any of their employees, makes any warranty, express or implied, or assumes any legal liability or responsibility for the accuracy, completeness, or usefulness of any information, apparatus, product, or process disclosed, or represents that its use would not infringe privately owned rights. Reference herein to any specific commercial product, process, or service by trade name, trademark, manufacturer, or otherwise does not necessarily constitute or imply its endorsement, recommendation, or favoring by the United States Government or any agency thereof. The views and opinions of authors expressed herein do not necessarily state or reflect those of the United States Government or any agency thereof. 


\section{DISCLAIMER}

Portions of this document may be illegible in electronic image products. Images are produced from the best available original document. 
Non-nuclear explosions are one of the initiating events (accidents) considered in the U.S. Nuclear Regulatory Commission study of formal methods for estimating the airborne release of radionuclides from fuel cycle facilities. Methods currently available to estimate the energetics and mass airborne release from the four types of non-nuclear explosive events (fast and slow physical explosions and fast and slow chemical explosions) are reviewed. The likelihood that fast physical explosions will occur in fuel cycle facilities appears to be remote and this type of explosion is not considered. Methods to estimate the consequences of slow physical and fast chemical explosions are available. Methods to estimate the consequences of slow chemical explosions are less well defined. An empirical fit to the fractional airborne release measured for the various conditions provides a "bounding value" for the airborne release and was found to be:

$\log$ (weight percent airborne) $=$

$$
-2.6+\sqrt{18.8\left(\log E / M_{0}-\left(\log E / M_{0}\right)^{2}-67.2\right.}
$$

where $E=$ source of energy, dyne-cm

$M_{0}=$ weight of inert material, gram

$\left(E / M_{O}^{O}\right.$ is expressed in dyne $\left.-\mathrm{cm} / \mathrm{g}\right)$ 



\section{EXECUTIVE SUMMARY}

This document presents the results of an initial effort undertaken by the Pacific Northwest Laboratory (PNL) to find methods to define the mass and energy release anticipated from non-nuclear explosive events postulated for fuel cycle facilities. This effort is a portion of a PNL study to provide the U.S. Nuclear Regulatory Commission (NRC) with techniques to more precisely evaluate the radiological impacts from industrial-type accidents in nuclear fuel cycle facilities.

Non-nuclear explosive events fall into four classes that are based upon the types of reactions that generate the energy (physical or chemical) and the rate at which the energy is generated (fast or slow).

The potential for fast physical explosions in fuel cycle facilities is limited to the reaction between molten glass and water. Numerous studies have demonstrated that the potential for this type of reaction is remote. This type of reaction was not considered any further.

A variety of standard fluid flow equations were adequate for calculating the mass and energy releases from slow physical explosive events. The hoopstress equation provides a good estimate for the pressure at which process vessels could rupture, and the thermal expansion equation provides a "conservative" estimate of the total energy released from a rupture. Mass releases could be estimated based upon the results of PNL experiments on the airborne releases that result from venting pressurized powders and liquids (Sutter 1983). Basic thermodynamic equations provide mass and energy releases from "flashing sprays" (venting of liquids heated beyond their boiling points), with particle size definitions provided by the experiments of Brown and York (1962).

The TNT-equivalent concept provides a simple solution to the energy release characteristics for fast chemical explosions. Mass release characteristics can be estimated from an empirical model developed by Steindler and Seefeldt (1980). No methods were identified for dealing specifically with the characteristics of airborne releases from powders as a result of fast chemical explosions. One of the events of concern is a "red-oil" (nitrated organic solvents) explosion, and the data from Nichols (1960) and applicable to define the energy release from such an explosion. The shear-stress model described by Martin et al. (1983) provides a means of estimating the airborne release from external shock waves generated by a "red-oil" explosion.

In the absence of methods for specifically estimating the mass releases from slow chemical explosions, the methods described above for fast chemical explosions can be applied. However, great care must be used when choosing the parameters to define the event.

For explosive events where the definition of parameters that describe the mass airborne release characteristics is limited, a "bounding" expression for 
the mass release from explosive events was developed based upon the findings from PNL's experimental studies and the Steindler and Seefeldt model. The equation is:

$$
\begin{aligned}
& \log \text { (weight percent airborne) }= \\
& -2.6+\sqrt{18.8\left(\log E / M_{0}\right)-\left(\log E / M_{0}\right)^{2}-67.2}
\end{aligned}
$$

where $E$ = energy applied, dyne-cm

$M_{0}=$ weight of inert material, gram

$\left(E / M_{0}^{O}\right.$ is expressed in dyne-cm/g) 


\section{CONTENTS}

ABSTRACT

ii i

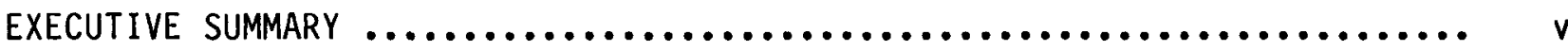

1.0 INTRODUCTION.......................................... 1

2.0 CONCLUSIONS AND RECOMMENDATIONS..$\ldots \ldots \ldots \ldots \ldots \ldots \ldots \ldots \ldots \ldots \ldots \ldots$

3.0 DEFINITION OF MASS AND ENERGY RELEASES FROM EXPLOSIVE EVENTS........ 5

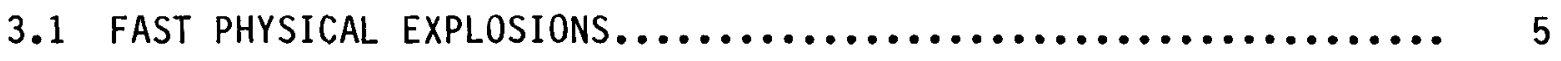

3.2 SLOW PHYSICAL EXPLOSIONS.............................. 7

3.3 FAST CHEMICAL EXPLOSIONS............................. 19

3.4 SLOW CHEMICAL EXPLOSIONS............................ 34

4.0 MODELING OF PNL EXPERIMENTAL RESULTS $\ldots \ldots \ldots \ldots \ldots \ldots \ldots \ldots \ldots \ldots \ldots$

5.0 References........................................... 41 


\section{FIGURES}

3.1 Bursting Pressure Versus Vessel Diameter....................... 13

3.2 Shock Wave Parameters for Hemispherical TNT Surface Burst

at Sea Leve1.............................................. 21

3.3 Extrapolation of Explosive Dispersal Data to High Mass Ratios....... 22

3.4 Amount Initially Aerosolized Versus Mass Ratio.................. 23

4.1 PNL Experimental Results and Curve Fits...................... 38

\section{TABLES}

3.1 Process Vessel Characteristics $. . . \ldots \ldots \ldots \ldots \ldots \ldots \ldots \ldots \ldots \ldots \ldots, 11$

3.2 Typical Mechanical Properties of Structural Materials............... 11

3.3 TNT Equivalence for Various Materials Released During Vessel Rupture Events..................................... 15

3.4 Cumulative Probability Distribution......................... 25

3.5 Explosion Cloud Volume................................ 26

3.6 Heat of Reaction of Tributyl Phosphate Nitration................. 27

3.7 Correction for Concentration of Nitrate in the Organic Phase at Zero Time............................................. 28

3.8 Coefficient of Rate Equation for Tributyl Phosphate Nitrate Reaction............................................... 28

4.1 Mass Ratio and E/M Examples.............................. 39 


\subsection{INTRODUCTION}

The Pacific Northwest Laboratory ( $P N L$ ) is engaged in an effort to provide the U.S. Nuclear Regulatory Commission (NRC) with techniques to more precisely evaluate the radiological consequences of industrial-type accidents in nuclear fuel cycle facilities. Pacific Northwest Laboratory has provided descriptions of certain types of fuel cycle facilities and processes, in addition to data on the potential source terms (radioactive and energetics) for some of the accident types investigated. The initial accident type investigated was fire, and much of the investigation regarding fire has been completed. The second accident type is explosion, and this report addresses some of the preliminary findings of that investigation.

This report is an expansion and revision of an earlier informal report, Preliminary Concepts on Energetics and Mass Releases During Explosive Events in Fuel Cycle Facilities (Halverson and Mishima 1982). Since that report, some of our ideas on the characterization and modeling of the various explosive events have changed. Several new events are described, and the descriptions of old events are changed. The first section of the report contains a definition of the different events and their relationships to each other. The following sections describe the individual explosion types in greater detail, and the last section provides a method to quantify the fraction of the nonexplosive material that can be made airborne as a result of the explosive event, and the particle size distribution of the material made airborne. This report also provides a basic explanation of explosions, and examines some information from existing literature that can be used to define the source terms as they apply to nuclear fuel cycle facilities. 



\subsection{CONCLUSIONS AND RECOMMENDATIONS}

We have investigated potential analysis methods for energy and mass release during explosive events in fuel cycle facilities. Methods available as analysis tools varied greatly, depending on the type of explosion.

For fast physical explosions, only molten glass seems to have a potential for explosive events. This potential was judged to be very remote under nearnormal operating conditions. The mass or energy released from a glass spill would probably result in normal heat and mass transfer mechanisms, and would probably not result in explosion shock waves.

For slow physical explosions, a variety of standard fluid flow equations are sufficient to calculate energy and mass flow from ruptured vessels. The hoop-stress equation for rupture pressure provides a good estimate. The isothermal expansion equation provides a conservative estimate of the total energy release in a rupture-type event. The data of Sutter (1983) on pressurized release of liquids and powders provide mass fraction release estimates for those cases involving pressurized powders or liquids. Particle size and flow rate information is available for flashing sprays. The particle size data of Brown and York (1962) combined with basic thermodynamics provide an adequate solution.

The TNT-equivalent concept provides a simple solution to the energy release characteristics for fast chemical explosions. Mass release information for metals and liquids is available from the model of Steindler and Seefeldt (1980). No information is currently available on the explosive dissemination of powders. Data from Nichols (1960) are applicable to the red-oil explosion. The method of Martin et al. (1983) represents the best source term for powders made airborne by an external shock wave.

For slow chemical explosions, the methods used for fast chemical explosions can be used if applied carefully. Great care must be taken in choosing parameters, and a wide range of answers will probably be generated.

An overall bounding expression for mass releases from explosive events, based on PNL's experimental program and the Steindler-Seefeldt equation, is presented. This equation is an upper limit, empirically derived, and is easily adapted to computer calculations. 



\subsection{DEFINITION OF MASS AND ENERGY RELEASES FROM EXPLOSIVE EVENTS}

The term "explosion" denotes any situation where a source of high-pressure gas moves rapidly toward equilibrium with its surroundings. High-pressure gas may be generated in one of two ways: by the rupture of a vessel or pipe containing high-pressure gas, resulting in a physical explosion, or by a chemical reaction that occurs during a highly exothermic (heat-releasing) reaction, resulting in a chemical explosion. This section presents examples of physical and chemical explosions, and compares the relationship between four classes of explosions in terms of physical or chemical explosions and the rate of energy release.

Physical explosions may include the rupture of boilers, steam lines, and pressurized-gas cylinders. Another example would be the so-called "steam explosion" that may result when molten metal is dropped into a water bath. The release of energy in a steam explosion occurs very rapidly (on the order of microseconds to milliseconds) upon fragmentation of the molten metal into fine droplets. The release of energy in a rupture event generally occurs over a period of tens of milliseconds to seconds. Chemical reactions that result in an explosion usually require an initial ignition source of energy, but are self-sustaining after ignition. The explosion of TNT or any explosive material is an example of this type of explosion, as is the rapid burning of a room full of methane or natural gas. A TNT explosion might release its energy in a period of up to a millisecond. Rapid burning might release its energy over a period of several seconds.

The rate of energy release has a large influence on the course of the explosion and its effect on the surroundings. When energy is released slowly, normal energy and mass transfer mechanisms such as convection and diffusion are adequate to remove the accumulated energy and mass from the area of the explosion, but if energy is released quickly, these mechanisms are not adequate. A shock front forms as a result of the accumulated energy. An arbitrary time of about one millisecond can be chosen as the division between "fast" and "slow" energy releases. "Fast" explosions have energy 'release rates on the order of microseconds to milliseconds, while "slow" explosions have energy release rates on the order of milliseconds to seconds.

Combining the energy types (physical and chemical explosions) with the energy release times results in four classes of explosions: fast physical explosions, slow physical explosions, fast chemical explosions, and slow chemical explosions. Fast chemical explosions are typically called detonations, and slow chemical explosions are typically called deflagrations.

\subsection{FAST PHYSICAL EXPLOSIONS}

Fast physical explosions involve the rapid release of a physically generated, high-pressure gas. The prime example of a fast physical explosion is the steam explosion that can occur when a molten material with a low melting point, such as a metal, glass, or salt, is dropped into water or an aqueous solution. As the molten material sinks through the water, its surface cools and 
solidifies but its core remains fluid because of the low melting point. If water is trapped within the molten material when the surface of the material has solidified (e.g., when the material reaches the bottom of a pool of water, adheres to the floor of the container, and traps a pocket of water), the trapped water is heated to steam and expands, fracturing the partially solidified material. If the material is subdivided by the expansion into particles that have a diameter of $200 \mu \mathrm{m}$ or less, heat transfer from the particles to the water is very high, and large amounts of steam are produced rapidly. This almost instantaneous release of a large volume of steam generates a shock front.

In a nuclear fuel cycle facility, a steam explosion could result in radioactive releases if the molten material submerged in the aqueous solution is uranium or plutonium, or if the material contains radioactive materials. In the first case, a heavy metal or heavy-metal oxide aerosol could be formed when the uranium or plutonium is fractured by the steam. In the second case, some fraction of the radionuclides contained within the liquid is bound to be entrained by the steam. The liquid droplets formed could then dry and provide small radioactive particles.

The probability of a steam explosion in a nuclear fuel cycle facility is very low. The only operation being considered for use in a nuclear fuel cycle facility that involves large quantities of molten material is the glass melter proposed for use in waste vitrification. The accidental introduction of coolant water into molten glass has been studied (Postma, Chapman and Buelt 1980), and the results of this study show that no violent interactions have occurred during world wide use to this date and that destructive water/glass interactions are low-probability events if they can occur at all. An additional study of essentially the same system (Hutcherson et a1. 1984) resulted in the conclusion that the largest steam explosion that could occur would involve $0.1 \mathrm{~kg}$ of water. The glass melter designed for use at West Valley was analyzed and found to be capable of withstanding an explosion involving $5 \mathrm{~kg}$ of water, although the probability of $5 \mathrm{~kg}$ of water being involved in an explosion was considered vanishingly small.

Discussions with Fauske and Associates (Burr Ridge, Illinois), who were involved in the Hutcherson study, and with Corning Glass Works (Corning, New York) personnel indicated that the possibility of a glass/water steam explosion is controlled mainly by the viscosity of the glass. Corning personnel indicated that they did not feel a steam explosion could take place in glass with a viscosity over about $1 \mathrm{P}$, while Hutcherson et al. (1984) presented the results of a study by Robinson and Fry indicating glass fragmentation occurring below about $5 \mathrm{P}$. These results would indicate that as long as the glass viscosity remained above about $5 \mathrm{P}$, no explosion would be expected. For the borosilicate glass currently specified for waste vitrification, the viscosity is normally much higher than $5 \mathrm{P}$. For the normal glass melter operating range of about $1050^{\circ} \mathrm{C}$ to $1200^{\circ} \mathrm{C}$, the glass viscosity ranges from about $200 \mathrm{P}$ to about $50 \mathrm{P}$. Thus, we would asume no explosions under normal operating conditions with borosilicate glass. 
Abnormalities in melter operating conditions or errors in the preparation of glass-forming material could result in glass melts caused by low-viscosity glass. If melter instrumentation and control were to fail, the melter could operate at such a high temperature that the glass viscosity would drop to about 5 P. According to Hutcherson et al. (1984), a glass temperature of about $1400^{\circ} \mathrm{C}$ would be necessary for such a low viscosity. At such a high temperature, it is possible that the materials used to construct the melter could begin to melt. (Note that $1400^{\circ} \mathrm{C}$ refers to the bulk glass temperature, and the electrodes in the melter might be even hotter.) For glass viscosity to approach $1 \mathrm{P}$, a glass temperature of about $1500^{\circ} \mathrm{C}$ to $1600^{\circ} \mathrm{C}$ would be necessary. A more detailed analysis of the melter is necessary to determine if such high temperatures could be reached.

An improperly mixed batch of glass-forming material could produce a lowviscosity glass, which could result in a glass melt. However, analyzing each batch of glass-forming material after it is mixed should eliminate the possibility of glass melts.

Even if a low-viscosity glass is produced, a steam explosion is not probable, because the glass must be mixed with water for a steam explosion to occur. To be mixed with water, either the glass must be poured from the melter into water or water must enter the melter. The first case could occur if, in the case of catastrophic rupture of the melter, glass pours from the melter into a pool of water below the melter. An unlikely event must occur to form a water pool under the melter, such as a rupture of cooling coils or of water or liquid waste storage tanks, or flooding.

Hutcherson et al. (1984) discussed the possibility of water being introduced into a glass melter. Up to $0.1 \mathrm{~kg}$ of water was shown to be present in the melter under normal conditions. The steam explosion produced by that much water was shown to be containable in the melter planned for West valley. The maximum amount of water that could reside in the melter under stable film boiling conditions was shown to be about $1 \mathrm{~kg}$, which is not enough water to cause rupture of the melter in the case of a steam explosion.

From this discussion it can be seen that the probability of a steam explosion external to the melter depends on three rare events--a process control error resulting in a low-viscosity glass, rupture of the melter, or a separate process failure or rupture producing a pool of water. A steam explosion inside the melter could involve only one process control error, the production of a low-viscosity glass, but the results of this explosion should be contained. Even if a second process control error is added (excess water in melter) the expected explosion should be contained.

The overall probability of a steam explosion producing a measurable radioactive release is very low and no further consideration of the problem will be made. 


\subsection{SLOW PHYSICAL EXPLOSIONS}

Slow physical explosions result from the slow release of a physically generated high-pressure gas. Typical explosions include the rupture of a highpressure gas cyclinder or pressure vessel, the rupture of a high-pressure steam line, and boiler ruptures. The rupture of gas cylinders found in nuclear fuel cycle facilities [Department of Transportation (DOT) type 1A standard cylinder] generally results in a missile hazard rather than an explosive release. The catastrophic rupturing of process vessels has the greatest potential for energy releases in nuclear fuel cycle facilities because the rupture may cause a pressurized release of gaseous radioactive material, or powder or liquid material. If the material in the vessel is not radioactive, the pressure wave generated by a rupture may cause the release of other radioactive materials.

The simplest slow physical explosion involves the release of a pressurized gas over a period of up to several seconds. An example of this type of explosion is the release of a radioactive gas from a cylinder through a broken fitting or ruptured cylinder wall. Bird, Stewart and Lightfoot (1960) present a solution for the expansion of an ideal gas through a frictionless, adiabatic orifice. The instantaneous discharge rate for the gas is:

$$
w=S \sqrt{2 P_{1} \rho_{1}\left(\frac{\gamma}{\gamma-1}\right)\left[\left(\frac{P_{2}}{P_{1}}\right)^{\frac{2}{\gamma}}-\left(\frac{P_{2}}{P_{1}}\right)^{\frac{\gamma+1}{\gamma}}\right]}
$$

where $w=$ instantaneous mass flow rate

$S=$ area of orifice opening

$P_{1}=$ pressure inside the tank at time $t$

$\rho_{1}=$ vapor density in tank at time $t$

$\frac{1}{\gamma}=$ heat capacity ratio of vapor $=C_{p} / C_{y}$

$P_{2}=$ pressure at nozzle opening at time $t$

This expression leads to an equation for the discharge time to reach any specific mass fraction of the original fluid remaining:

$$
t=\frac{v / s}{\sqrt{2\left(\frac{\gamma}{\gamma-1}\right)\left(\frac{P_{0}}{\rho_{0}}\right)} \int_{\frac{P_{1}}{\rho_{0}}}^{1}} \frac{d \eta}{\sqrt{\left(\frac{P_{2}}{P_{0}}\right)^{\frac{2}{\gamma}} n^{\gamma-1}-\left(\frac{P_{2}}{P_{0}}\right)^{1+\frac{1}{\gamma}}}}
$$




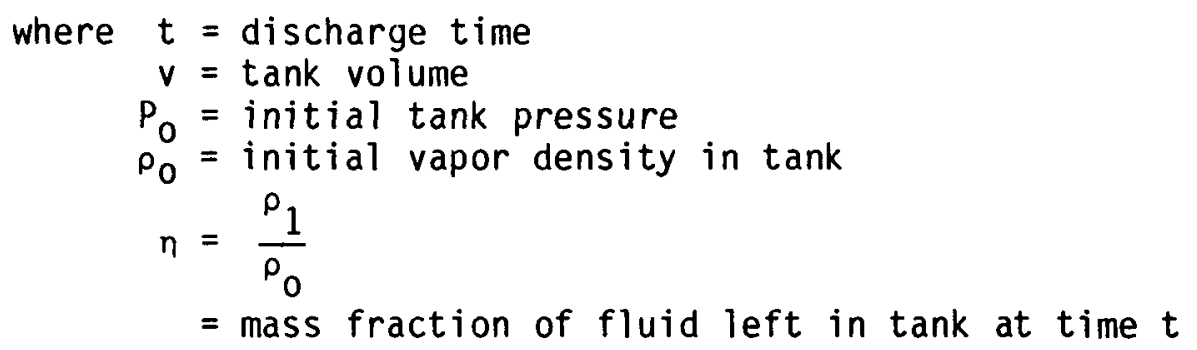

There is no simple analytical solution to the integral on the right side of the equation, so the calculation must be performed numerically. The pressure at the nozzle opening, $P_{2}$, must be carefully evaluated. At lower flow rates (low tank pressure), $P_{2}$ is equal to the ambient pressure. At higher tank pressures, the flow rate reaches a maximum value and becomes independent of the ambient pressure. The critical pressure ratio $(r)$ defines the change between high and low pressures, and is given by:

$$
\left.r=\left(\frac{P_{2}}{P_{1}}\right) \underset{\text { crit }}{\gamma+1}\right)^{\gamma / \gamma-1}
$$

If $P_{2} / P_{1}<r$, then the instantaneous discharge rate is:

$$
W_{\max }=S \sqrt{\gamma P_{1} \rho_{1}\left(\frac{2}{\gamma+1}\right)^{\frac{\gamma+1}{\gamma-1}}}
$$

The analytical solution for the discharge time equation [Equation (2)] is:

$$
t=\frac{v / S}{\sqrt{\gamma\left(\frac{\rho_{0}}{\rho_{0}}\right)\left(\frac{2}{\gamma+1}\right)^{\frac{\gamma H}{\gamma-1}}}}\left(\frac{2}{\gamma-1}\right)\left[\left(\frac{\rho_{1}}{\rho_{0}}\right)^{\frac{1-\gamma}{2}}-1\right]
$$

To solve an actual problem, Equation (4) would be used to calculate discharge times from the time the tank is full $\left(P_{1}=P_{0}\right)$ to the time the critical pressure ratio is reached $\left(P_{1}=P_{2} / r\right)$. Equation (2) would then be used to determine the remainder of the release. For gases similar to air and for normal atmospheric conditions, Equation (2) would not be used until $P_{1}$, the tank pressure, falls to about $2 \mathrm{~atm}$. For initial tank pressures that are very high (20 atm or above), most of the material in the tank would be released in accordance with Equation (4), and Equation (2) would not be necessary. For tanks that rupture at low pressures, Equation (2) could describe a large portion of the release. 
In terms of accident analysis, Equation (4) predicts a more rapid release of material than Equation (2). Therefore, Equation (4) would be more conservative than Equation (2) in determining blast effects. In determining aerosol production and transport, Equation (4), which predicts a slightly shorter time for the same material release, is probably also conservative.

The solution of the problems described above would involve the construction of a plot of $n$ versus $t$ using Equation (4). From this plot, a plot of $M_{0}$ $(1-n)$ versus $t$, with $M_{0}$ the initial mass of material in the tank, can be constructed. This plot determines the amount of material released to the environment as a function of time. This plot may be used as input to EXPAC in the form of mass added per unit time. [EXPAC is the nuclear fuel cycle facility aerosol transport code developed by the Los Alamos National Laboratory (LANL).]

The total energy release of the tank rupture can be calculated by assuming either an adiabatic or isothermal expansion of the gas. The isothermal expansion calculations are conservative and tend to overestimate damage, and are therefore preferred (Grelecki 1972). The isothermal expansion expression for the total energy of a confined gas is:

$$
E=1.26 \vee\left(\frac{P_{0}}{1 \text { atm }}\right)\left(\frac{2730 \mathrm{~K}}{T_{0}}\right) R T_{0} \ln \left(\frac{P_{0}}{P_{2}}\right)
$$

$$
\text { where } \begin{aligned}
E & =\text { energy, calories } \\
V & =\text { volume of vessel, } \mathrm{ft}^{3} \\
P_{0} & =\text { initial pressure of gas, atm } \\
T_{0} & =\text { initial temperature of gas, }{ }^{\circ} \mathrm{K} \\
R & =\text { gas constant }=1.987 \frac{\mathrm{cal}}{\mathrm{g-mole}{ }^{0} \mathrm{~K}} \\
\mathrm{P}_{2} & =\text { pressure outside the tank }
\end{aligned}
$$

Equation (6) determines the maximum amount of energy that could be released from the tank. If it is assumed that all the energy of the system is released with the mass in the form of kinetic energy, then the fractional release of energy with time will be the same as the fractional mass release with time, and the procedure described for the fractional mass release ( $n$ ) in the above equations will apply.

The previous energy and mass release calculations depend on the pressure of the gas at the time of rupture, and the gas pressure depends on the size, thickness, and material used to construct the process vessel. The range of sizes and materials for process vessels found in various types of nuclear fuel cycle facilities is shown in Table 3.1. These dimensions and properties can be used in a variety of equations to predict the bursting pressure of the vessel. The mechanical properties for fuel cycle materials are listed in Table 3.2.

The most commonly used equation for determining stress on process vessels that are made of ductile materials is the hoop-stress equation (Alexander 1981; 
TABLE 3.1. Process Vessel Characteristics(a)

\begin{tabular}{|c|c|c|c|c|}
\hline $\begin{array}{c}\text { Fuel Cycle } \\
\text { Facility Processes } \\
\end{array}$ & $\begin{array}{c}\text { Process Vessel } \\
\text { Materials } \\
\end{array}$ & $\begin{array}{l}\text { Thickness, } \\
\text { in. }\end{array}$ & $\begin{array}{c}\text { Diameter, } \\
\mathrm{ft}\end{array}$ & $\begin{array}{c}\text { Length, } \\
\mathrm{ft}\end{array}$ \\
\hline$M 0_{x}$ fuel fabrication & Stainless steel & up to $1 / 4$ & $0.3-6$ & $1.15-32$ \\
\hline Fuel reprocessing & $\begin{array}{l}\text { Stainless steel } \\
\text { Titanium }\end{array}$ & up to $1 / 4$ & $\begin{array}{l}0.3-11 \\
6\end{array}$ & $\begin{array}{l}18 \\
10\end{array}$ \\
\hline Solidification & $\begin{array}{l}\text { Stainless steel } \\
\text { Hastelloy } X\end{array}$ & up to $1 / 4$ & $\overline{3}^{---}$ & --- \\
\hline
\end{tabular}

(a) Dimensions and materials from Jenkins, Murphy and Schneider 1979; Schneider et al. 1982; Smith, Konzek and Kennedy 1978.

TABLE 3.2. Typical Mechanical Properties of Structural Materials

\begin{tabular}{|c|c|c|}
\hline Material & $\begin{array}{l}\text { Ultimate Tensile) } \\
\text { Strength (psi) } \\
\end{array}$ & $E u^{(b)}$ \\
\hline $\begin{array}{l}\text { Carbon Steel } \\
\text { AISI-SAE } 1020\end{array}$ & 65,000 & --- \\
\hline 304 SS & 82,000 & 0.585 \\
\hline Titanium alloy & 144,000 & --- \\
\hline Hastelloy $\mathrm{X}$ & 110,000 & --- \\
\hline
\end{tabular}

(a) Values from Perry, Green and Maloney 1984.

(b) Values from Royer, Rolfe and Easley 1973.

Marin and Sauer 1954; Barsom and Rolfe 1970). The stress caused by the expansion of the gas in the vessel is equated with the ultimate tensile strength of the material used to construct the vessel. The resulting equation is:

$$
\sigma=S_{P}=\frac{P D}{2 t}
$$

where $\sigma=$ ultimate tensile strength, psi

$$
\begin{aligned}
S_{p} & =\text { hoop stress, psi } \\
& =\text { burst pressure, psi } \\
t & =\text { thickness of material, in. } \\
D & =\text { outside diameter of vessel, in. }
\end{aligned}
$$


This equation is solved for $P$ to give

$$
P=\frac{2 t_{\sigma}}{D}
$$

Several other equations have been empirically derived for process vessels that have been fatigued by repeated cycling of pressure or by notching of the walls. One such equation is the Bach equation (Barsom and Rolfe 1970):

$$
\sigma=P\left(\frac{1.3 D^{2}+0.4 \partial^{2}}{D^{2}-\partial^{2}}\right)
$$

where $\sigma=$ ultimate tensile strength, psi

$P=$ bursting pressure, $p$ si

$D=$ outside diameter, in.

$\partial=$ inside diameter, in.

This can be solved for $P$ as

$$
P=\frac{\sigma\left(D^{2}-\partial^{2}\right)}{1.3 D^{2}+0.4 \partial^{2}}
$$

The modified Svensson equation (Barsom and Rolfe 1970) has also been used:

$$
P=\sigma F_{c y l}\left(\frac{2 t}{d}\right)\left(1-\frac{t}{\partial}\right)
$$

where $\quad P=$ bursting pressure, psi

$\sigma=$ ultimate tensile strength, psi

$\mathrm{t}=$ thickness of vessel, in.

$\mathrm{d}=$ inside diameter of vessel, in.

$F_{c y l}=$ cohesion factor for cylinders

$$
=\left(\frac{0.25}{\varepsilon_{u}+0.227}\right)\left(\frac{e}{\varepsilon_{u}}\right)^{\varepsilon_{u}}
$$

where $\varepsilon_{u}=$ true strain rate at maximum $10 \mathrm{~g}$

$\mathrm{e}=$ base of natural $\log$

If Equations (7), (9), and (11) are applied to estimate the failure pressure of a 304 stainless steel process vessel that is 60 inches in diameter with 1/4-in.-thick walls, values of 683,804 , and 519 psi are found for the 
hoop-stress, Bach, and modified Svensson methods, respectively. The hoopstress calculation generates a value between the other two methods, and is used hereafter.

Figure 3.1 is a plot of the bursting pressures versus vessel diameter, based on the hoop-stress equation, for vessels of various materials as a function of wall thickness. Although Table 3.1 indicates a range of diameters from $4 \mathrm{in}$. to $11 \mathrm{ft}$, the very small-diameter vessels and equipment are found in only a few locations and are for very specialized functions. The diameters of "normal" process vessels are probably greater than $4 \mathrm{ft}$, and bursting pressure for these vessels is normally less than 1000 psi.

The energy generated by the depressurization of gas can be estimated using several assumptions. Several scenarios are postulated in Table 3.3 to compare the TNT equivalency of some explosions possible in nuclear fuel cycle facilities with the TNT equivalency of explosions resulting from vessel failure. One of the most discussed accidents in a reprocessing facility is the red-oil accident discussed under fast chemical explosions. The TNT equivalency per cubic foot of gas released from a vessel, assuming isothermal expansion of the gas at $1000 \mathrm{psi}$ and at $20^{\circ} \mathrm{C}$, is greater than the energy anticipated to be released per pound of "red oil," and greater than the energy estimated from an ion exchange explosion. The quantity of gas anticipated to be released is much greater than the quantity of "red oil"; therefore, process vessel failure appears to be one of the nuclear fuel cycle facility accidents capable of generating very high energy levels.

The high TNT equivalency of process vessel failures is not an indication that the damage from a vessel rupture would be equivalent to the damage from an explosion of TNT. The energy released during a vessel rupture is still much slower than that released during a TNT explosion, so direct comparison of the explosion effects cannot be made. Some comparison of the pressures generated by the explosion could be made using a model such as EXPAC.

A method for estimating the total amount of energy released from the rupture of a vessel containing gaseous material is given below. Consider a cylindrical tank of radius $r$ and height $h$. The tank has a rupture pressure, $P_{1}$, calculated from the previously described hoop-stress method. Isothermal expansion of the gas is assumed, so the energy release can be described in an energy equation as

$$
E^{\prime}=n R T \ln \frac{P_{1}}{P_{2}}
$$

where $E^{\prime}=$ energy, calories

$$
\begin{aligned}
n & =\text { number of g-moles of gas in vessel } \\
R & =\text { gas constant }=1.987 \frac{\text { cal }}{\text { g-mole }{ }^{\circ} \mathrm{C}} \\
T & =\text { gas temperature, }{ }^{\circ} \mathrm{K} \text { (rupture) pressure of gas, atm } \\
P_{1} & =\text { initial (rual atm } \\
P_{2} & =\text { final pressure of gas (probably } 1 \text { atm), atm }
\end{aligned}
$$




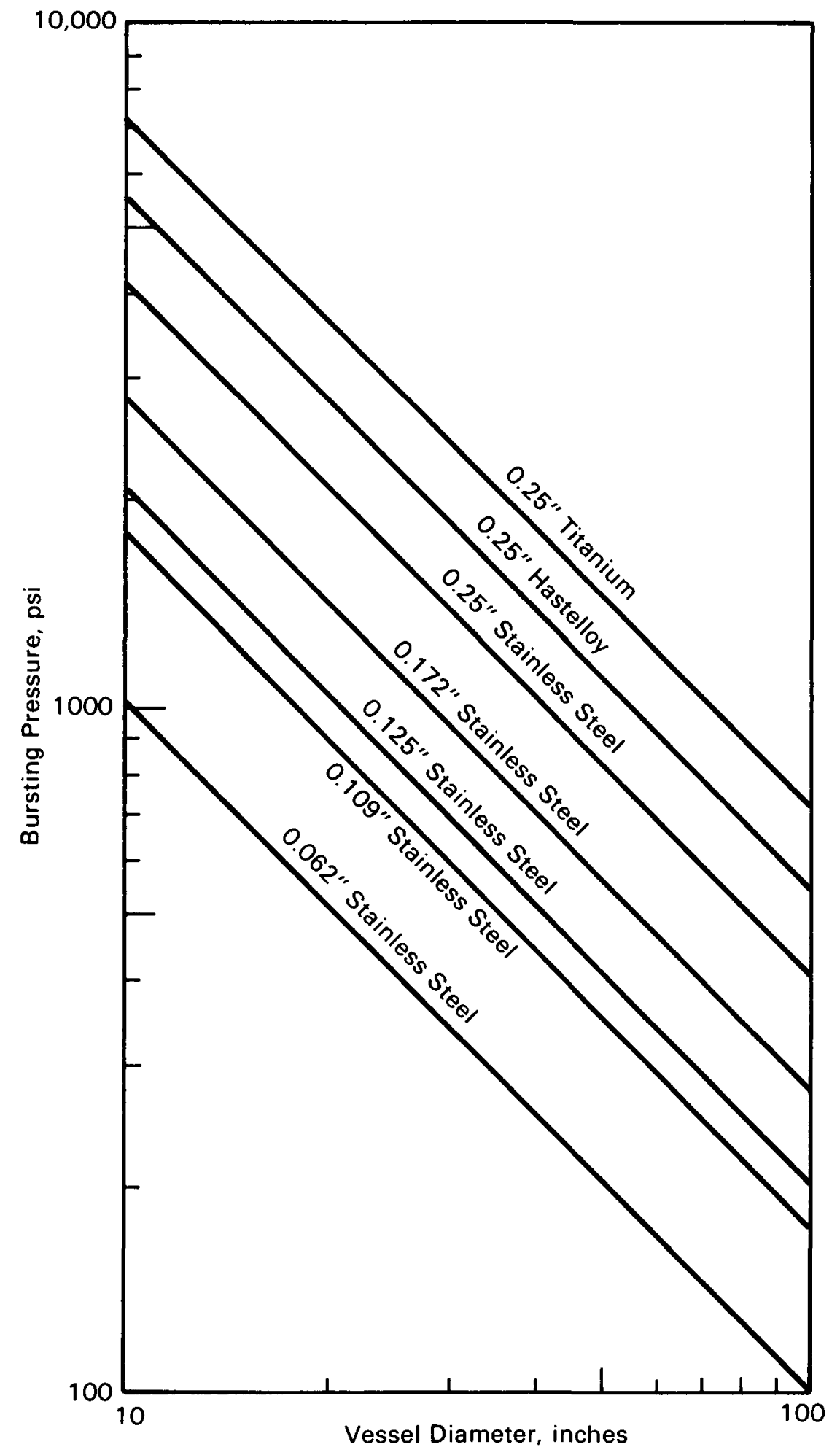

FIGURE 3.1. Bursting Pressure Versus Vessel Diameter 
TABLE 3.3. TNT Equivalence for Various Materials Released During Vessel Rupture Events

Material and Conditions

Mineral oil $\left(20 \mathrm{ksi}, 20^{\circ} \mathrm{C}\right)(\mathrm{a})$
Argon $\left(20 \mathrm{ksi}, 20^{\circ} \mathrm{C}\right)(\mathrm{a})$
Hydrogen gas $\left(20 \mathrm{ksi}, 20^{\circ} \mathrm{C}\right)(\mathrm{a})$
Hydrogen gas released to atmospher
secondary explosion, $50 \%$ efficien
Gas $\left(10 \mathrm{ksi}, 20^{\circ} \mathrm{C}\right)$ (b)
Gas $\left(1 \mathrm{ksi}, 20^{\circ} \mathrm{C}\right)(\mathrm{b})$
Gas $\left(0.1 \mathrm{ksi}, 20^{\circ} \mathrm{C}\right)$ (b)
Americium ion exchange explosion
(6-in.-dia SS tube, 36 in. long,
$0.13-i n .-$ thick wall (c)ssumes
rupture at 100 psi) (c)
"Red oil" explosion (d)

Pound TNT Equivalence Per Cubic Foot of Material Released Under Stated Conditions

$$
\begin{aligned}
& \sim 0.06 \\
& \sim 1.0 \\
& \sim 1.7
\end{aligned}
$$

Note: 1 lb TNT is equivalent to the release of 1830 BTU, or about $5 \times 10^{5} \mathrm{cal}$.

(a) Pohto (1979)

(b) Grelecki (1972). Isothermal expansion is assumed.

(c) Grelecki (1976). Presented for comparison purposes.

(d) Nichols (1960).

The number of moles of gas in the vessel is given by $n=\frac{P_{1} V}{R T}$, where $V$ is the volume of the vessel in cubic feet and the other terms are as defined in Equation (12). The energy equation can now be written $E=P_{1} V$ in $P_{1} / P_{2}$, where $E$ is now in $\mathrm{ft}^{3} / \mathrm{atm}$. We apply the conversion factor of $1 \mathrm{cat}=0.01458^{\prime} \mathrm{ft}^{3} / \mathrm{atm}$ to obtain $E=685.76 P_{1} V$ in $P_{1} / P_{2}$, where $E$ is now again in calories. If $P_{2}$ is equal to $1 \mathrm{~atm}$, then $E^{1}=685.76 \beta_{1} V_{1} \ln P_{1}$. We now substitute from the hoopstress equation [Equation (8)] for $\beta_{1}$

$$
P_{1}^{\prime}=\frac{\sigma 2 t}{D}=\frac{\sigma t}{r}
$$




$$
\text { where } \begin{aligned}
\mathrm{P}_{1}^{\prime} & =\text { bursting pressure, psi } \\
\sigma & =\text { ultimate tensile strength, psi } \\
t & =\text { thickness of vessel wall, } \mathrm{ft} \\
D & =\text { outside diameter of vessel, in. } \\
r & =\text { radius of vessel }
\end{aligned}
$$

We convert $P_{1}^{\prime}$ to atmospheres:

$$
P_{1}=\frac{P_{1}^{\prime}}{14.7}=\frac{\sigma t}{14.7 r}
$$

Substituting back into the energy equation we get

$$
E=46.64 \frac{\sigma t}{r} \ln \frac{\sigma t_{j}}{14.7 r}
$$

For a cylinder, $v=\pi r^{2} h$, so

or

$$
E=46.65 \pi(\sigma \times t \times h \times r) \ln \frac{\sigma t}{14.7 r}
$$

$$
E=146.6(\sigma \times t \times h \times r) \ln \frac{\sigma t}{14.7 r}
$$

where $E$ = energy, calories

$$
\begin{aligned}
& \sigma=\text { ultimate tensile strength, psi } \\
& t=\text { thickness of material, ft } \\
& h=\text { height of vessel, ft } \\
& r=\text { radius of vessel, ft }
\end{aligned}
$$

As stated previously, the energy can be considered to exit the container at the same rate as the gas.

Another type of slow physical explosion involves the release of a pressurized gas mixed with a powder or liquid, such as the rupture of a container of powder that has been pressurized because of radiolytic gases. An extensive experimental program was conducted at PNL to measure aerosol generation during these types of releases (Sutter 1983). In these experiments, powders and liquids were pressurized at up to $1000 \mathrm{psi}$ and released quickly through a rupture disk. (Note that the upper bound of $1000 \mathrm{psi}$ is about what we anticipate as the bursting pressure of a "normal" process vessel.) Modeling of these releases is currently under way, and preliminary modeling efforts have raised several questions requiring additional experiments. These experiments were performed in 1985.

The physical processes involved in the release of pressurized powders or liquids are complex and vary with each situation. During the release of a pressurized powder, the gas expanding in the interstices of the bulk powder provides the energy necessary to disperse the powder. The location of the rupture, relative to the powder level, is probably not an important factor because of the almost instantaneous expansion of the bulk powder that occurs where the 
container ruptures and the confining pressure is lost. The experiments mentioned above (Sutter 1983) were performed with the rupture occurring above the powder level.

In the release of pressurized liquids, the pressure in the system may be due to a gas above the liquid, a gas dissolved in the liquid, or vapors generated by the heated liquid. The release may occur above or below the liquid level.

For liquids pressurized by a cover gas, the location of the rupture may be important because a rupture above the liquid surface could cause a suction-type force on the liquid as the cover gas exits, which would cause the release of some liquid. A rupture below the liquid level could involve much higher releases; conceivably, all of the liquid could be released. The release may be in the form of a liquid spray rather than a relatively quick release.

For liquids pressurized by a soluble gas, the situation may be similar to that of pressurized powders. The gas dissolved in the liquid will come out of solution when the confining pressure is released, which will cause the bulk liquid to expand and then exit the container. The location of the rupture should not be as important in this case.

During a pressurized-liquid release resulting from a superheated liquid generating vapors, part of the liquid flashes to vapor and part remains as a liquid. The flashing of part of the liquid causes the jet of fluid exiting the container to break into small droplets. If the initial conditions of the liquid in the container are known, and the final temperature of the liquid drops exiting the rupture is known, a simple enthalpy balance gives the fraction of the liquid that vaporizes.

$$
M C_{L}\left(T_{L}-T_{0}\right)=m_{v} \lambda+m_{L} C_{L}\left(T_{F}-T_{0}\right)
$$

where $M=$ mass of liquid leaving tank before flashing

$m_{v}=$ mass of vapor formed by flashing

$m_{L}=$ mass of liquid droplets left after flashing

$C_{L}^{L}=$ specific heat of the liquid, ${ }^{\circ} \mathrm{C}$

$T_{L}=$ temperature of 1 iquid in tank, ${ }^{\circ} \mathrm{C}$

$T_{F}^{L}=$ temperature of droplets outside of the tank, ${ }^{\circ} \mathrm{C}$

$T_{0}^{F}=$ thermodynamic reference temperature, ${ }^{\circ} \mathrm{C}$

$\ell=$ heat of vaporization of liquid

If the thermodynamic reference temperature, $T_{0}$, is set to $T_{F}$, the equation above may be rewritten as:

$$
\begin{gathered}
M C_{L}\left(T_{L}-T_{F}\right)=m_{V} \lambda+m_{L} C_{L}\left(T_{F}-T_{F}\right) \\
\text { or } \\
M C_{L}\left(T_{L}-T_{F}\right)=m_{V} \lambda
\end{gathered}
$$


Then $\frac{m_{v}}{M}=\frac{C_{L}\left(T_{L}-T_{F}\right)}{\lambda}=$ mass fraction of liquid that flashes to vapor.

The fraction of the liquid remaining in droplet form is:

$$
\frac{M-m_{v}}{M}=1-\frac{m_{v}}{M}=1-\frac{C_{L}\left(T_{L}-T_{F}\right)}{\lambda}
$$

This simple enthalpy balance neglects any heat losses to the container during the release, and also neglects heat transfer to and from the atmosphere outside the tank. The problem with the simple enthalpy balance is that the exit temperature of the liquid droplets must be specified, which is not a simple task unless measurements are available. The temperature depends on the thermodynamics of the system and is path dependent.

If thermodynamic data for the system are available, a simple enthalpyentropy balance procedure is preferred (Owczarski 1981). Assuming an isentropic expansion of the liquid and knowing the initial conditions, the final temperature and the vapor-liquid ratios may be read from the thermodynamic table or graph. This method has the added attraction of predicting the exit velocity of the gas based on the enthalpy change of the fluid. If potential energy changes are neglected, an energy balance of the fluid gives:

$$
\Delta H=1 / 2 U_{0}^{2}
$$

where $\Delta H=$ change in enthalpy, energy/mass

$U_{0}=$ velocity, length/time

This equation gives the maximum possible velocity of the exiting fluid. For a container holding a fixed amount of material, the time to drain the container can be evaluated from:

$$
t_{b}=V_{0} / A U_{L}
$$

where $t_{b}=$ blowdown time

$V_{0}=$ volume of the liquid in the container

$A=$ area of the break or rupture

$U_{L}=$ liquid equivalent velocity $=U_{0} \frac{\rho_{0}}{\rho_{\ell}}$

$\rho_{0}=$ two-phase density of the mixture exiting the container

$\rho_{\ell}=$ density of the liquid.

The equivalent liquid velocity $\left(U_{L}\right)$ is used because $V_{0}$ is based on a liquid, while $U_{0}$ is based on the two-phase flow through the break.

The size of the droplets formed by the flashing spray has been observed experimentally. Brown and York (1962) present an empirical curve fit of their 
data on flashing sprays of superheated water. The linear mean diameter of the droplets correlated well with the Weber number and the temperature of the jet. The relationship:

$$
\overline{\mathrm{D}}_{10}=(1840-5.18) \mathrm{T} / \mathrm{N}_{\mathrm{We}}
$$

where $\bar{D}_{10}=$ linear mean diameter of the droplets, $\mu \mathrm{m}$

$T=$ temperature of the jet, ${ }^{\circ} \mathrm{F}$

$$
\begin{aligned}
N_{W e} & =\text { Weber number }=\frac{\rho_{g} U_{L}^{2} d}{2 \sigma} \\
\rho_{g} & =\text { density of the gas phase surrounding the jet } \\
U_{L} & =\text { velocity of the jet } \\
d & =\text { diameter of the jet (assumed equivalent to diameter of rupture) } \\
\sigma & =\text { surface tension of the liquid }
\end{aligned}
$$

The droplet distribution fits a log-normal probability function as well as any other distribution. Standard deviation of 1.5 to 2.5 were obtained by Brown and York.

\subsection{FAST CHEMICAL EXPLOSIONS}

Fast chemical explosions, detonations, result from the rapid release of chemical energy. These explosions occur on the order of microseconds to milliseconds, and result in the sudden, violent blast associated with the word

"explosion." Detonation of TNT is the most common example of a fast chemical explosion. A less common example is the detonation of a combustible gas mixture. The explosion of greatest concern in nuclear fuel cycle facilities is the "red oil" explosion discussed later in this section.

The "TNT-equivalent" method is the simplest way to model detonations. This method is discussed in many references (Grelecki 1972; Baker et al. 1983; and numerous other sources). The method is sometimes referred to as blast scaling and involves comparing the blast effects of a given compound with a known amount of TNT, a compound that has been extensively studied in explosion literature. It is assumed that for equivalent energy releases, the blast effects should be similar. This approximation is reasonably good for condensed phase explosives.

The TNT-equivalent method is based on the comparison of the heat of combustion of a given material and TNT, and involves calculating the

TNT-equivalent weight. TNT has a heat of combustion of about $1,940 \mathrm{Btu} / 1 \mathrm{~b}$ or $1080 \mathrm{cal} / \mathrm{g}$. The equations for calculating the TNT-equivalent weight are: 


$$
\begin{aligned}
& \text { TNT-equivalent weight }(1 \mathrm{~b})=H_{c}(B t u / 1 b) / 1,940 \times \begin{array}{c}
\text { weight of material } \\
(1 \mathrm{~b})
\end{array} \\
& \text { TNT-equivalent weight }(\mathrm{g})=\mathrm{H}_{\mathrm{c}}(\mathrm{cal} / \mathrm{g}) / 1,080 \times \text { weight of material }
\end{aligned}
$$
where $H_{c}=$ heat of combustion of the material.

The major problem with this method is that not all materials burn completely during an explosion; therefore, the heat of explosion may be somewhat less than the heat of combustion. However, values for the heat of explosion are available for few compounds, while values for the heat of combustion are available for many compounds and can be estimated from bond energies for other compounds. For most materials, using the value for the heat of combustion instead of the actual heat of explosion should be conservative.

Another problem with using the TNT-equivalent method to estimate explosion effects is that for materials with a much different density and/or heat of combustion from TNT, the geometry of the source can have an effect. For example, consider a hypothetical compound with a heat of combustion of $100 \mathrm{cal} / \mathrm{g}$ and a density half that of TNT. A 10-1b sphere of this hypothetical compound would release as much energy as a 1-lb sphere of TNT, but would occupy a volume 20 times the volume of the TNT sphere. The radius of the sphere would be 2.7 times the radius of the TNT sphere. These differences in geometry can lead to differences in blast effects close to the explosion source, although the differences tend to disappear farther away from the source.

Once a TNT-equivalent weight is obtained, experimental curves for TNT can be used to find blast parameters. The most important parameter for our work is the peak side-on overpressure (called the peak positive incident pressure and denoted $P_{\text {so }}$ ). This curve is shown in Figure 3.2. Note that the distance from the source is scaled by the cube root of the TNT-equivalent weight. Many other experimentally measured blast parameters are available in Baker et al. (1983), Grelecki (1972), and from the Departments of the Army, Navy, and Air Force (1969).

The blast wave can be affected if the wave is reflected off the surface below the blast. If the surface is immovable, such as a floor, the reflection makes it appear as though the energy source is doubled. Applying blast parameters of free air bursts, as opposed to those of surface bursts, could result in inaccuracies when estimating damages from detonations, unless the "doubling effect" is accounted for. We chose to assume surface burst parameters because an explosion in a nuclear fuel cycle facility is likely to occur close to a floor or other hard surface, with the exception of a very small explosion in a large canyon.

The parameters described above are useful for estimating the damage from a detonation, but the main concern in a nuclear fuel cycle facility is the airborne radioactive release. Steindler and Seefeldt (1980) present a model for calculating the aerosol mass and mass median particle diameter for detonations involving condensed phase explosives and inert material. The model is based on 


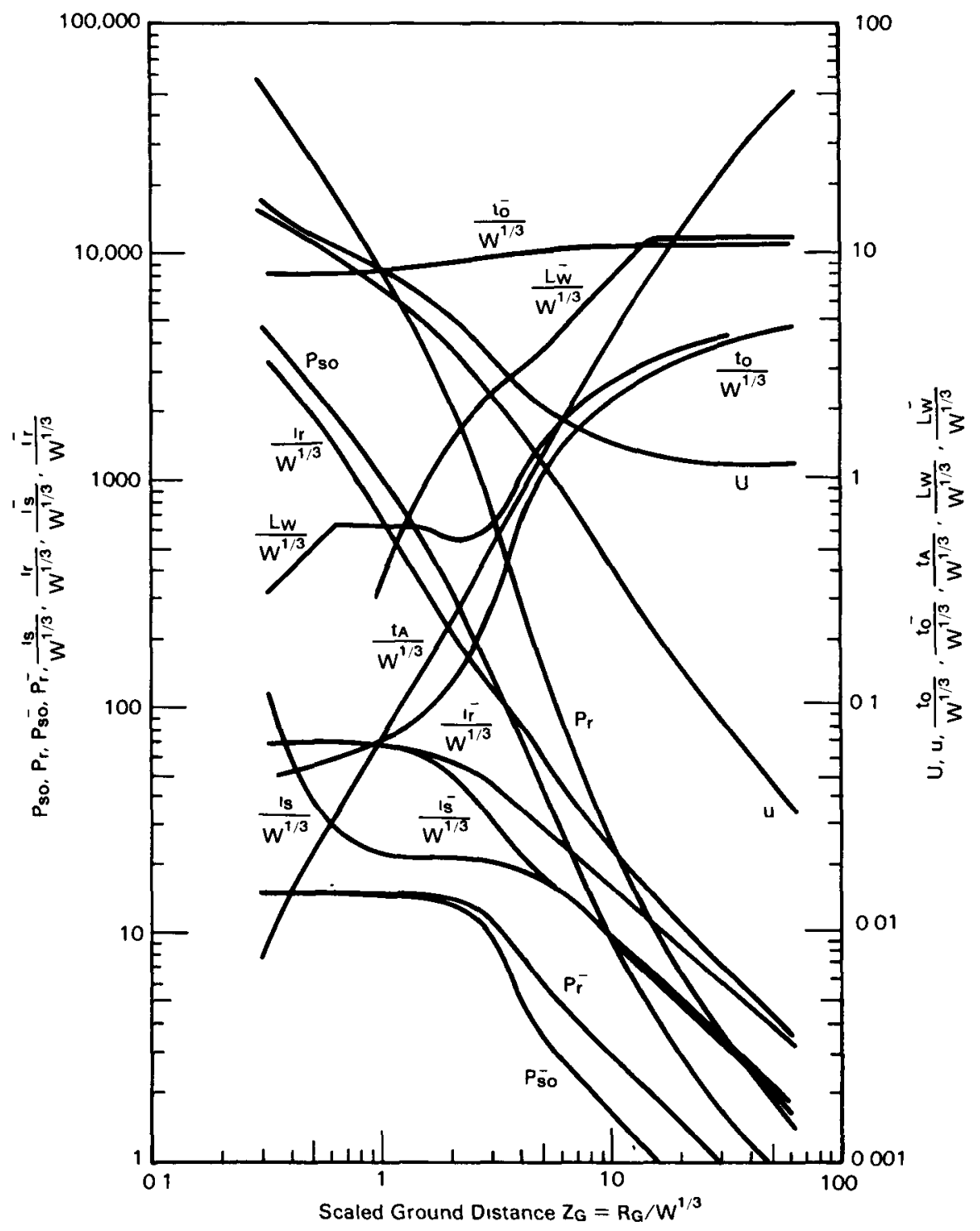

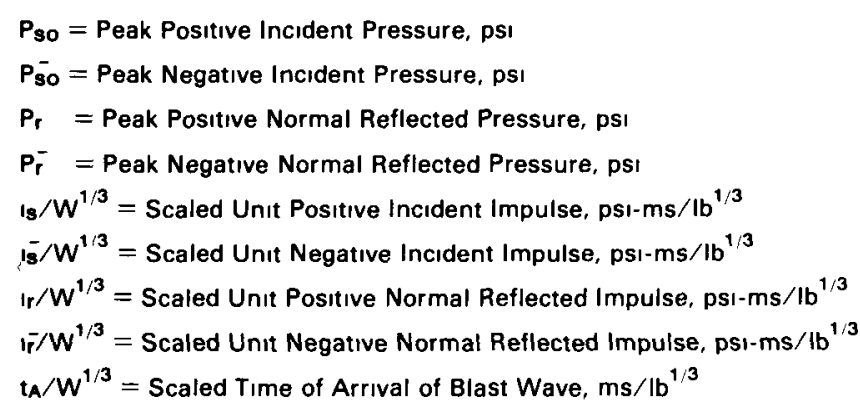

to $/ \mathrm{W}^{1 / 3}=$ Scaled Positive Duration of Positive Phase, $\mathrm{ms} / \mathrm{lb}^{1 / 3}$

to $/ W^{1 / 3}=$ Scaled Negative Duration of Positive Phase, $\mathrm{ms} / \mathrm{lb}^{1 / 3}$

$\mathrm{LW} / \mathrm{W}^{1 / 3}=$ Scaled Wave Length of Positive Phase, $\mathrm{ft} / \mathrm{Ib}^{1 / 3}$

$L \bar{W} / W^{1 / 3}=$ Scaled Wave Length of Negative Phase, $\mathrm{ft} / \mathrm{lb}^{1 / 3}$

$\mathrm{U}=$ Shock Front Velocity, $\mathrm{ft} / \mathrm{ms}$

$\mathrm{u}=$ Partıcle Velocity, $\mathrm{ft} / \mathrm{ms}$

$W=$ Charge Weight, ib

$R=$ Radial Distance from Charge, $\mathrm{ft}$

$Z_{G}=$ Scaled Ground Distance, $\mathrm{ft} / \mathrm{lb}^{1 / 3}$

\section{FIGURE 3.2. Shock Wave Parameters for Hemispherical TNT Surface Burst at Sea Level}


extrapolation of published information on the explosive dispersal of chemical agents in both solid and liquid forms. A seven-step method for using their model is described as follows:

Step 1 - Estimate the mass ratio (MR) (ratio of the weight of inert material to the weight of explosive). The weight of explosives is the TNT-equivalent weight of the explosive material.

Step 2 - Estimate the mass median particle diameter $\left(d_{g}\right)$ from Figure 3.3.

Step 3 - Estimate the amount of the inert material initially made to aerosol from Figure 3.4 or from the equation:

initial amount made to aerosol $=2.783(M R)^{0.3617}$ in $\mathrm{g}$ aerosol $/ \mathrm{g}$ explosive

The total initial amount made to aerosol equals the initial amount made to aerosol times the equivalent weight of the explosive.

Step 4 - Select the aerosol size ranges that are of interest in the particular case under consideration. Often 0 to $3 \mu \mathrm{m}, 3$ to $10 \mu \mathrm{m}$, and 10 to $100 \mu \mathrm{m}$ will provide adequate aerosol fractionation. For each particle size range, apply Steps 5 through 7.

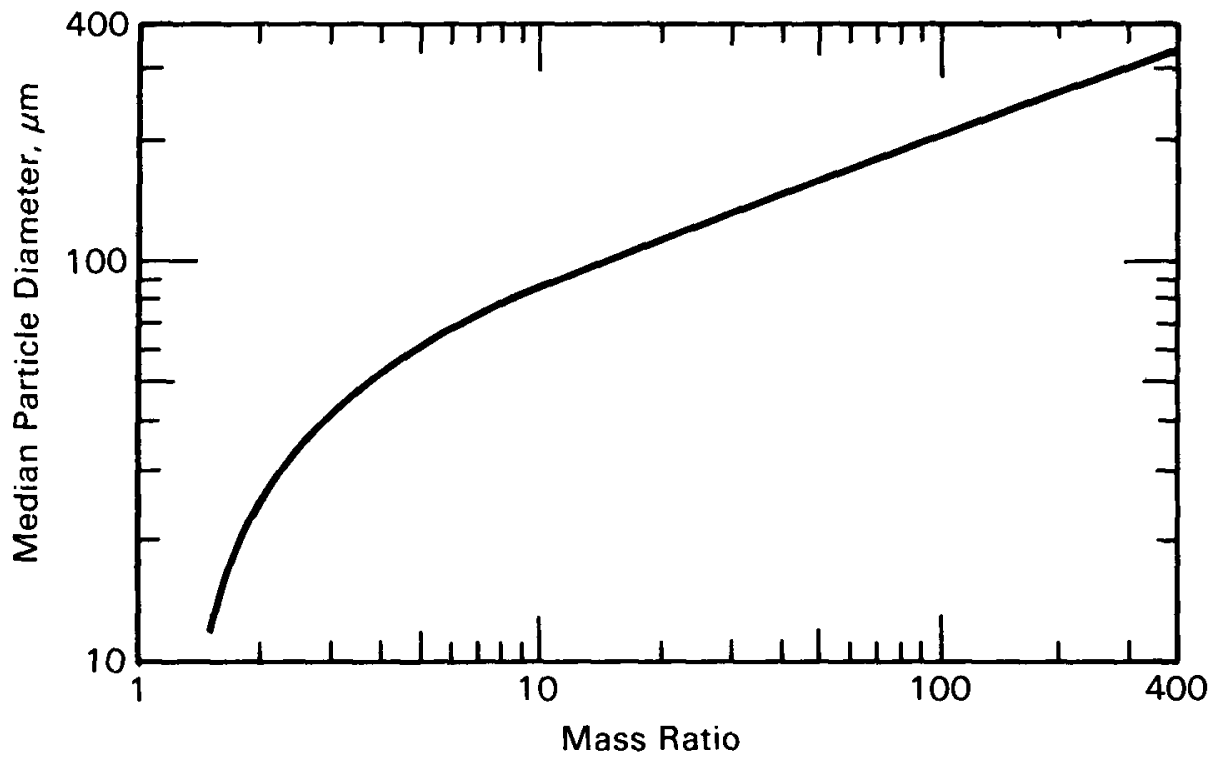

FIGURE 3.3. Extrapolation of Explosive Dispersal Data to High Mass Ratios 


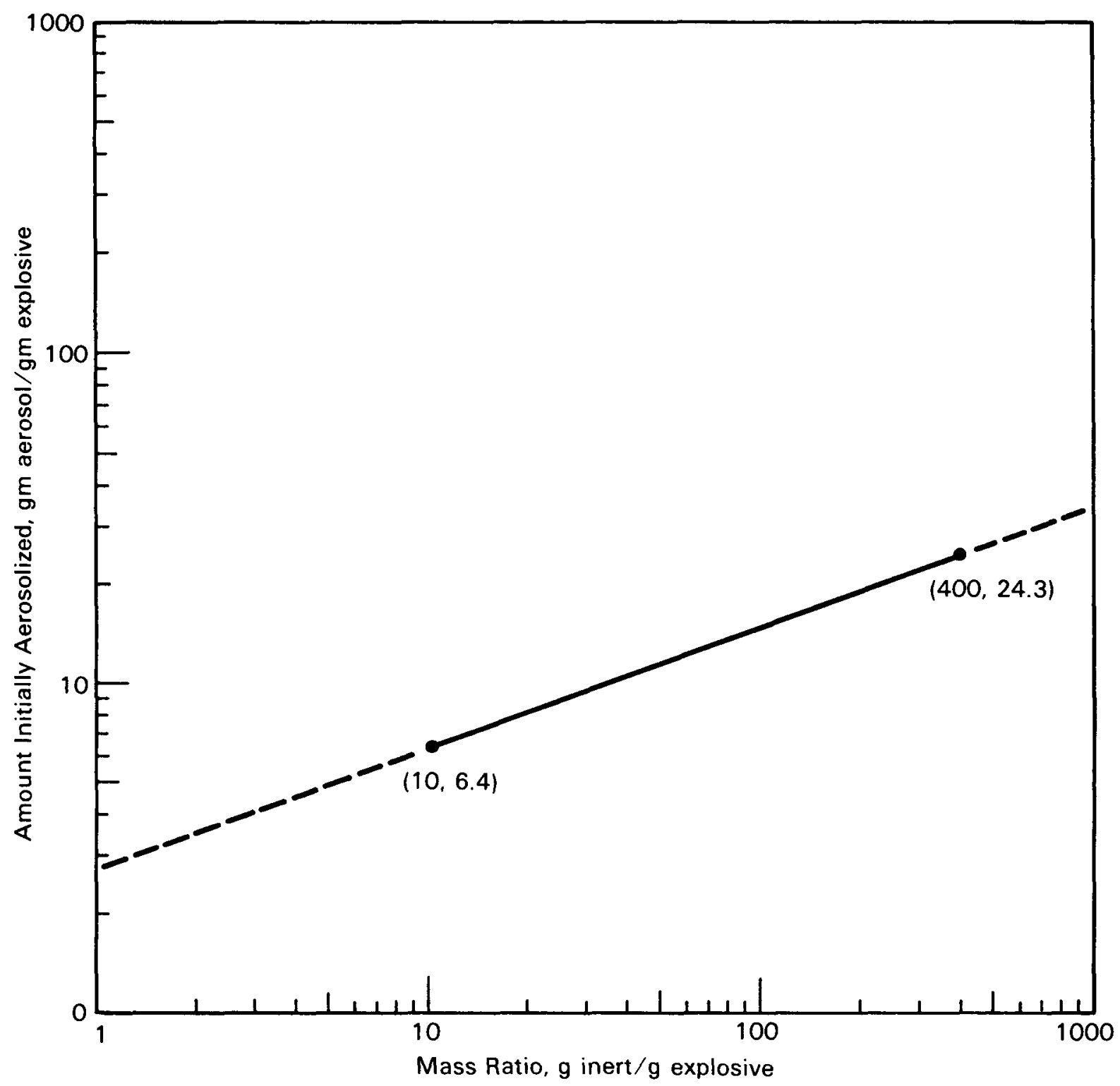

FIGURE 3.4. Amount Initially Aerosolized Versus Mass Ratio

Step 5 - Calculate standard normal deviate $(z)$ :

$$
Z=\frac{\left(\ln d-\ln d_{g}\right)}{\ln \sigma_{g}} \text { at each endpoint }(d) \text { of the size fraction }
$$

where $\sigma_{g}$ is the assumed standard deviation of the aerosol size distribution.

Steinder and Seefeldt use $\sigma_{g}=2$ in their work, but any known or assumed value can be used. 
Step 6 - Calculate the percent of aerosol in each size range by subtracting the two endpoint values of the cumulative normal frequency distribution $[P(Z)]$ in Table 3.4 .

Step 7 - Multiply the percent of the aerosol in each range by the total initial amount made to aerosol to get the total weight initially made to aerosol in each size range.

Steindler and Seefeldt state that for use in safety analyses, their method requires experimental validation of the extrapolation of the reference data to the conditions existing in the nuclear fuel cycle facility. The problem is that most of the available data are at low values of the MR parameter, while MR is expected to be at 100 to 400 in a nuclear fuel cycle facility. Also, the Steindler-Seefeldt model is not directly applicable to dispersion of powders by explosives. The theoretical basis of the model is based on the assumption that it takes a certain amount of energy to generate a certain amount of new surface area from a solid or liquid, and a certain amount of energy is also required to disperse this new area (in the form of a powder or droplet) away from the source. If powder is the source material, little new surface area is formed, so most of the energy goes into dispersing the material, and the SteindlerSiefeldt model will typically underpredict the weight fraction of the airborne powder. Our pressurized powder release experiments indicate that this underprediction may be an order of magnitude or more.

The Steindler-Siefeldt model has been coded in DETIN, a computer code designed as the explosion source term for EXPAC. The DETIN code is still undergoing major additions and modifications, but early versions are available for use now.

Most aerosol calculations require knowing the total aerosol mass and the volume of the gas involved (the particle mass concentration). In an explosion, large amounts of aerosol may be released in a roughly spherical cloud, and knowing the radius of the cloud would be useful. Lee et al. (1977) state that for gaseous explosions, the instantaneous volume of the cloud of particles and combustion products occupies the same volume as the original explosive mixture. For "weak blasts" (deflagrations), the cloud radius is typically 1.8 times the initial radius (Lee et a1. 1977). These clouds are immediately subject to dispersion and buoyant effects as a result of the heating of the combustion gases.

For condensed phase (solid) explosions, no clear results of the cloud radius are mentioned in the literature. Some researchers have chosen the socalled "characteristic length" of the explosion as the radius ( $r$ ) of the cloud (Oston 1981). The expression $\left(E / P_{0}\right) I / 3$, where $E$ is the source energy and $P_{0}$ is the initial gas pressure, has units of length. The expression is based on Sach's extension of the blast scaling curves at sea level to high altitude explosions (Sachs 1944). The characteristic length of the explosion turns out to be the point at which the peak side-on overpressure reaches between $0.3 \mathrm{P}_{0}$ and $0.9 \mathrm{P}_{0}$, depending on which set of experimental data is chosen. A good average value would be $0.5 \mathrm{P}_{0}$. This is a rather arbitrary radius, but is the only one available. 


\begin{tabular}{|c|c|c|c|c|c|c|c|c|c|c|c|}
\hline 2 & \multicolumn{3}{|c|}{$P(z)$} & $\frac{2}{1.30}$ & \multicolumn{3}{|c|}{$P(z)$} & \multirow{2}{*}{$\begin{array}{l}z \\
2.60 \\
2.62 \\
2.64 \\
2.66 \\
2.68\end{array}$} & \multicolumn{3}{|c|}{$P(z)$} \\
\hline $\begin{array}{l}0.00 \\
0.02 \\
0.04 \\
0.06 \\
0.08\end{array}$ & $\begin{array}{l}0.50000 \\
0.50797 \\
0.51595 \\
0.52392 \\
0.53188\end{array}$ & $\begin{array}{l}00000 \\
83137 \\
34368 \\
21826 \\
13720\end{array}$ & $\begin{array}{l}00000 \\
16902 \\
52831 \\
54107 \\
13988\end{array}$ & $\begin{array}{l}1.30 \\
1.32 \\
1.34 \\
1.36 \\
1.38\end{array}$ & $\begin{array}{l}0.90319 \\
0.90658 \\
0.90987 \\
0.91308 \\
0.91620\end{array}$ & $\begin{array}{l}95154 \\
24910 \\
73275 \\
50380 \\
66775\end{array}$ & $\begin{array}{l}14390 \\
06528 \\
35548 \\
52915 \\
84986\end{array}$ & & $\begin{array}{l}0.99533 \\
0.99560 \\
0.99585 \\
0.99609 \\
0.99631\end{array}$ & $\begin{array}{l}88119 \\
35116 \\
46986 \\
29674 \\
88919\end{array}$ & $\begin{array}{l}76281 \\
51879 \\
38964 \\
25147 \\
90825\end{array}$ \\
\hline $\begin{array}{l}0.10 \\
0.12 \\
0.14 \\
0.16 \\
0.18\end{array}$ & $\begin{array}{l}0.53982 \\
0.54775 \\
0.55567 \\
0.56355 \\
0.57142\end{array}$ & $\begin{array}{l}78372 \\
84260 \\
00048 \\
94628 \\
37159\end{array}$ & $\begin{array}{l}77029 \\
20584 \\
05907 \\
91433 \\
00901\end{array}$ & $\begin{array}{l}1.40 \\
1.42 \\
1.44 \\
1.46 \\
1.48\end{array}$ & $\begin{array}{l}0.91924 \\
0.92219 \\
0.92506 \\
0.92785 \\
0.93056\end{array}$ & $\begin{array}{l}33407 \\
61594 \\
63004 \\
49630 \\
33766\end{array}$ & $\begin{array}{l}66229 \\
73454 \\
65673 \\
34106 \\
66669\end{array}$ & $\begin{array}{l}2.70 \\
2.72 \\
2.74 \\
2.76 \\
2.78\end{array}$ & $\begin{array}{l}0.99653 \\
0.99673 \\
0.99692 \\
0.99710 \\
0.99728\end{array}$ & $\begin{array}{l}30261 \\
59041 \\
80407 \\
99319 \\
20550\end{array}$ & $\begin{array}{l}96960 \\
84109 \\
81350 \\
23774 \\
77299\end{array}$ \\
\hline $\begin{array}{l}0.20 \\
0.22 \\
0.24 \\
0.26 \\
0.28\end{array}$ & $\begin{array}{l}0.57925 \\
0.58706 \\
0.59483 \\
0.60256 \\
0.61026\end{array}$ & $\begin{array}{l}97094 \\
44226 \\
48716 \\
81132 \\
12475\end{array}$ & $\begin{array}{l}39103 \\
48215 \\
97796 \\
01761 \\
55797\end{array}$ & $\begin{array}{l}1.50 \\
1.52 \\
1.54 \\
1.56 \\
1.58\end{array}$ & $\begin{array}{l}0.93319 \\
0.93574 \\
0.93821 \\
0.94062 \\
0.94294\end{array}$ & $\begin{array}{l}27987 \\
45121 \\
98232 \\
00594 \\
65667\end{array}$ & $\begin{array}{l}31142 \\
81064 \\
88188 \\
05207 \\
62246\end{array}$ & $\begin{array}{l}2.80 \\
2.82 \\
2.84 \\
2.86 \\
2.88\end{array}$ & $\begin{array}{l}0.99744 \\
0.99759 \\
0.99774 \\
0.99788 \\
0.99801\end{array}$ & $\begin{array}{l}48696 \\
88175 \\
43233 \\
17949 \\
16241\end{array}$ & $\begin{array}{l}69572 \\
25811 \\
08458 \\
59596 \\
45106\end{array}$ \\
\hline $\begin{array}{l}0.30 \\
0.32 \\
0.34 \\
0.36 \\
0.38\end{array}$ & $\begin{array}{l}0.61791 \\
0.62551 \\
0.63307 \\
0.64057 \\
0.64802\end{array}$ & $\begin{array}{l}14221 \\
58347 \\
17360 \\
64332 \\
72924\end{array}$ & $\begin{array}{l}88953 \\
23320 \\
36028 \\
17991 \\
24163\end{array}$ & $\begin{array}{l}1.60 \\
1.62 \\
1.64 \\
1.66 \\
1.68\end{array}$ & $\begin{array}{l}0.94520 \\
0.94738 \\
0.94949 \\
0.54154 \\
0.95352\end{array}$ & $\begin{array}{l}07083 \\
38615 \\
74165 \\
27737 \\
13421\end{array}$ & $\begin{array}{l}00442 \\
45748 \\
25897 \\
33277 \\
36280\end{array}$ & $\begin{array}{l}2.90 \\
2.92 \\
2.94 \\
2.96 \\
2.98\end{array}$ & $\begin{array}{l}0.99813 \\
0.99824 \\
0.99835 \\
0.99846 \\
0.99855\end{array}$ & $\begin{array}{l}41866 \\
98430 \\
89387 \\
18047 \\
87580\end{array}$ & $\begin{array}{l}99616 \\
71324 \\
65843 \\
88262 \\
82660\end{array}$ \\
\hline $\begin{array}{l}0.40 \\
0.42 \\
0.44 \\
0.46 \\
0.48\end{array}$ & $\begin{array}{l}0.65542 \\
0.66275 \\
0.67003 \\
0.67724 \\
0.68438\end{array}$ & $\begin{array}{l}17416 \\
72731 \\
14463 \\
18897 \\
63034\end{array}$ & $\begin{array}{l}10324 \\
51751 \\
39407 \\
49653 \\
83778\end{array}$ & $\begin{array}{l}1.70 \\
1.72 \\
1.74 \\
1.76 \\
1.78\end{array}$ & $\begin{array}{l}0.95543 \\
0.95728 \\
0.95907 \\
0.96079 \\
0.96246\end{array}$ & $\begin{array}{l}45372 \\
37792 \\
04910 \\
60967 \\
20196\end{array}$ & $\begin{array}{l}41457 \\
08671 \\
21193 \\
12518 \\
51483\end{array}$ & $\begin{array}{l}3.00 \\
3.05 \\
3.10 \\
3.15 \\
3.20\end{array}$ & $\begin{array}{l}0.99865 \\
0.99885 \\
0.99903 \\
0.99918 \\
0.99931\end{array}$ & $\begin{array}{l}01020 \\
57932 \\
23968 \\
36477 \\
28621\end{array}$ & \\
\hline $\begin{array}{l}0.50 \\
0.52 \\
0.54 \\
0.56 \\
0.58\end{array}$ & $\begin{array}{l}0.69146 \\
0.69846 \\
0.70540 \\
0.71226 \\
0.71904\end{array}$ & $\begin{array}{l}24612 \\
82124 \\
24837 \\
02811 \\
26911\end{array}$ & $\begin{array}{l}74013 \\
53034 \\
84302 \\
50973 \\
01436\end{array}$ & $\begin{array}{l}1.80 \\
1.82 \\
1.84 \\
1.86 \\
1.88\end{array}$ & $\begin{array}{l}0.96406 \\
0.96562 \\
0.96711 \\
0.96855 \\
0.96994\end{array}$ & $\begin{array}{l}96808 \\
04975 \\
58813 \\
72370 \\
59610\end{array}$ & $\begin{array}{l}87074 \\
54110 \\
40836 \\
19248 \\
38800\end{array}$ & $\begin{array}{l}3.25 \\
3.30 \\
3.35 \\
3.40 \\
3.45\end{array}$ & $\begin{array}{l}0.99942 \\
0.99951 \\
0.99959 \\
0.99966 \\
0.99971\end{array}$ & $\begin{array}{l}29750 \\
65759 \\
59422 \\
30707 \\
97067\end{array}$ & \\
\hline $\begin{array}{l}0.60 \\
0.62 \\
0.64 \\
0.66 \\
0.68\end{array}$ & $\begin{array}{l}0.72574 \\
0.73237 \\
0.73891 \\
0.74537 \\
0.75174\end{array}$ & $\begin{array}{l}68822 \\
11065 \\
37003 \\
30853 \\
77694\end{array}$ & $\begin{array}{l}49927 \\
31017 \\
07139 \\
28664 \\
46430\end{array}$ & $\begin{array}{l}1.90 \\
1.92 \\
1.94 \\
1.96 \\
1.98\end{array}$ & $\begin{array}{l}0.97128 \\
0.97257 \\
0.97381 \\
0.97500 \\
0.97614\end{array}$ & $\begin{array}{l}34401 \\
10502 \\
01550 \\
21048 \\
82356\end{array}$ & $\begin{array}{l}83998 \\
96163 \\
59548 \\
51780 \\
48592\end{array}$ & $\begin{array}{l}3.50 \\
3.55 \\
3.60 \\
3.65 \\
3.70\end{array}$ & $\begin{array}{l}0.99976 \\
0.99980 \\
0.99984 \\
0.99986 \\
0.99989\end{array}$ & $\begin{array}{l}73709 \\
73844 \\
08914 \\
88798 \\
22003\end{array}$ & \\
\hline $\begin{array}{l}0.70 \\
0.72 \\
0.74 \\
0.76 \\
0.78\end{array}$ & $\begin{array}{l}0.75803 \\
0.76423 \\
0.77035 \\
0.77637 \\
0.78230\end{array}$ & $\begin{array}{l}63477 \\
75022 \\
00028 \\
27075 \\
45624\end{array}$ & $\begin{array}{l}76927 \\
20749 \\
35210 \\
62401 \\
14267\end{array}$ & $\begin{array}{l}2.00 \\
2.02 \\
2.04 \\
2.06 \\
2.08\end{array}$ & $\begin{array}{l}0.97724 \\
0.97830 \\
0.97932 \\
0.98030 \\
0.98123\end{array}$ & $\begin{array}{l}98680 \\
83062 \\
48371 \\
07295 \\
72335\end{array}$ & $\begin{array}{l}51821 \\
32353 \\
33930 \\
90623 \\
65062\end{array}$ & $\begin{array}{l}3.75 \\
3.80 \\
3.85 \\
3.90 \\
3.95\end{array}$ & $\begin{array}{l}0.99991 \\
0.99992 \\
0.99994 \\
0.99995 \\
0.99996\end{array}$ & $\begin{array}{l}15827 \\
76520 \\
09411 \\
19037 \\
09244\end{array}$ & \\
\hline $\begin{array}{l}0.80 \\
0.82 \\
0.84 \\
0.86 \\
0.88\end{array}$ & $\begin{array}{l}0.78814 \\
0.79389 \\
0.79954 \\
0.80510 \\
0.81057\end{array}$ & $\begin{array}{l}46014 \\
19464 \\
58067 \\
54787 \\
03452\end{array}$ & $\begin{array}{l}16604 \\
14187 \\
39551 \\
48192 \\
23288\end{array}$ & $\begin{array}{l}2.10 \\
2.12 \\
2.14 \\
2.16 \\
2.18\end{array}$ & $\begin{array}{l}0.98213 \\
0.98299 \\
0.98382 \\
0.98461 \\
0.98537\end{array}$ & $\begin{array}{l}55794 \\
69773 \\
26166 \\
36652 \\
12692\end{array}$ & $\begin{array}{l}37184 \\
52367 \\
27834 \\
16075 \\
24011\end{array}$ & $\begin{array}{l}4.00 \\
4.05 \\
4.10 \\
4.15 \\
4.20\end{array}$ & $\begin{array}{l}0.99996 \\
0.99997 \\
0.99997 \\
0.99998 \\
0.99998\end{array}$ & $\begin{array}{l}83288 \\
43912 \\
93425 \\
33762 \\
66543\end{array}$ & \\
\hline $\begin{array}{l}0.90 \\
0.92 \\
0.94 \\
0.96 \\
0.98\end{array}$ & $\begin{array}{l}0.81593 \\
0.82121 \\
0.82639 \\
0.83147 \\
0.83645\end{array}$ & $\begin{array}{l}98746 \\
36203 \\
12196 \\
23925 \\
69406\end{array}$ & $\begin{array}{l}53241 \\
85629 \\
61376 \\
33162 \\
72308\end{array}$ & $\begin{array}{l}2.20 \\
2.22 \\
2.24 \\
2.26 \\
2.28\end{array}$ & $\begin{array}{l}0.98609 \\
0.98679 \\
0.98745 \\
0.98808 \\
0.98869\end{array}$ & $\begin{array}{l}65524 \\
06161 \\
45385 \\
93745 \\
61557\end{array}$ & $\begin{array}{l}86502 \\
92744 \\
64054 \\
81453 \\
61447\end{array}$ & $\begin{array}{l}4.25 \\
4.30 \\
4.35 \\
4.40 \\
4.45\end{array}$ & $\begin{array}{l}0.99998 \\
0.99999 \\
0.99999 \\
0.99999 \\
0.99999\end{array}$ & $\begin{array}{l}93115 \\
14601 \\
31931 \\
45875 \\
57065\end{array}$ & \\
\hline $\begin{array}{l}1.00 \\
1.02 \\
1.04 \\
1.06 \\
1.08\end{array}$ & $\begin{array}{l}0.84134 \\
0.84613 \\
0.85083 \\
0.85542 \\
0.85992\end{array}$ & $\begin{array}{l}47460 \\
57696 \\
00496 \\
77003 \\
89099\end{array}$ & $\begin{array}{l}68543 \\
27265 \\
69019 \\
36091 \\
11231\end{array}$ & $\begin{array}{l}2.30 \\
2.32 \\
2.34 \\
2.36 \\
2.38\end{array}$ & $\begin{array}{l}0.98927 \\
0.98982 \\
0.99035 \\
0.99086 \\
0.99134\end{array}$ & $\begin{array}{l}58899 \\
95613 \\
81300 \\
25324 \\
36809\end{array}$ & $\begin{array}{l}78324 \\
31281 \\
54642 \\
69428 \\
74484\end{array}$ & $\begin{array}{l}4.50 \\
4.55 \\
4.60 \\
4.65 \\
4.70\end{array}$ & $\begin{array}{l}0.99999 \\
0.99999 \\
0.99999 \\
0.99999 \\
0.99999\end{array}$ & $\begin{array}{l}66023 \\
73177 \\
78875 \\
83403 \\
86992\end{array}$ & \\
\hline $\begin{array}{l}1.10 \\
1.12 \\
1.14 \\
1.16 \\
1.18\end{array}$ & $\begin{array}{l}0.86433 \\
0.86864 \\
0.87285 \\
0.87697 \\
0.88099\end{array}$ & $\begin{array}{l}39390 \\
31189 \\
68494 \\
55969 \\
98925\end{array}$ & $\begin{array}{l}53618 \\
57270 \\
37202 \\
48657 \\
44800\end{array}$ & $\begin{array}{l}2.40 \\
2.42 \\
2.44 \\
2.46 \\
2.48\end{array}$ & $\begin{array}{l}0.99180 \\
0.99223 \\
0.99265 \\
0.99305 \\
0.99343\end{array}$ & $\begin{array}{l}24640 \\
97464 \\
63690 \\
31492 \\
08808\end{array}$ & $\begin{array}{l}75404 \\
49447 \\
44652 \\
11376 \\
64453\end{array}$ & $\begin{array}{l}4.75 \\
4.80 \\
4.85 \\
4.90 \\
4.95\end{array}$ & $\begin{array}{l}0.99999 \\
0.99999 \\
0.99999 \\
0.99999 \\
0.99999\end{array}$ & $\begin{array}{l}89829 \\
92067 \\
93827 \\
95208 \\
96289\end{array}$ & \\
\hline $\begin{array}{l}1.20 \\
1.22 \\
1.24 \\
1.26 \\
1.28\end{array}$ & $\begin{array}{l}0.88493 \\
0.88876 \\
0.89251 \\
0.89616 \\
0.89972\end{array}$ & $\begin{array}{l}93297 \\
75625 \\
23029 \\
53188 \\
74320\end{array}$ & $\begin{array}{l}78292 \\
52166 \\
25413 \\
78700 \\
45558\end{array}$ & $\begin{array}{l}2.50 \\
2.52 \\
2.54 \\
2.56 \\
2.58\end{array}$ & $\begin{array}{l}0.99379 \\
0.99413 \\
0.99445 \\
0.99476 \\
0.99505\end{array}$ & $\begin{array}{l}03346 \\
22582 \\
73765 \\
63918 \\
99842\end{array}$ & $\begin{array}{l}74224 \\
84668 \\
56918 \\
36444 \\
42230\end{array}$ & 5.00 & $\begin{array}{r}0.99999 \\
{[(-6) 3}\end{array}$ & 3] 97133 & \\
\hline
\end{tabular}


For nuclear fuel cycle facilities, $r=\left(E / P_{0}\right)^{1 / 3}$ must be applied carefully. The equation was originally derived for free air bursts that are spherical in shape. During a surface burst, a hemispherical cloud is formed with an apparent $E$ of twice that actually present because of the reflection of the blast waves from the surface. The equation $r=\left(E / P_{0}\right)^{1 / 3}$ may be written as

$$
r=\left(\frac{E_{-}}{P_{0}}\right)^{1 / 3}=\left(\frac{2 W \times 2 \times 10^{13}}{10^{6}}\right)^{1 / 3}
$$

or $342 W^{1 / 3}$, where $W$ is the TNT equivalent weight (in pounds). A value of $10^{6} \mathrm{erg} / \mathrm{cm}^{3}$ has been substituted for $P_{0}$. This corresponds to $P_{0}=1$ atm. The term $2 W$ is the apparent TNT equivalent weight for a surface burst. The number of ergs in a pound of TNT is $2 \times 10^{13}$. The cloud radius $r$ calculated from this equation has units of centimeters. Table 3.5 shows the calculated radius (in meters) for various apparent TNT equivalent weights. Note that for a factor of a 10,000-1b change, there is only a factor of a $\sim 20 \mathrm{~m}$ change in the radius. Table 3.5 also lists the associated volumes of the cloud formed.

An explosion inside a facility may or may not fill the room in which it occurs, depending on the energy involved. For ease in modeling, it is assumed the cloud fills the whole volume of the room. In small rooms, this is probably the case because the cloud boundaries gradually diffuse outwards to fill the room. In very large rooms, the cloud cannot expand to fill the room before the ventilation system pulls it out of the room. The cloud may drift as a cohesive unit from the explosion source to the ventilation system, or it may form

TABLE 3.5. Explosion Cloud Volume

\begin{tabular}{|c|c|c|c|}
\hline $\begin{array}{c}\text { TNT } \\
\text { Equivalent } \\
\text { Weight } \\
\text { (1b) } \\
\end{array}$ & $\begin{array}{c}\text { Apparent } \\
\text { TNT } \\
\text { Equi valent } \\
\text { Weight } \\
(1 \mathrm{~b}) \\
\end{array}$ & $\begin{array}{l}\text { Cloud } \\
\text { Radius } \\
\quad(\mathrm{m}) \\
\end{array}$ & $\begin{array}{l}\text { Cloud } \\
\text { Volyme } \\
\left(\mathrm{m}^{3}\right)\end{array}$ \\
\hline 0.05 & 0.1 & 1.6 & 8.4 \\
\hline 0.25 & 0.5 & 2.7 & 42 \\
\hline 0.5 & 1 & 3.4 & 84 \\
\hline 2.5 & 5 & 5.9 & 420 \\
\hline 5 & 10 & 7.4 & 840 \\
\hline 25 & 50 & 12.6 & 4200 \\
\hline 50 & 100 & 15.9 & 8400 \\
\hline 250 & 500 & 27.1 & 42,000 \\
\hline 500 & 1000 & 34.2 & 84,000 \\
\hline
\end{tabular}


a type of plume. Conceivably, a cloud dispersion model could be used to model the path of the cloud, but perhaps an easier way to treat a large room, such as a canyon, would be to consider it a small room in series with several large sections of duct. The EXPAC could then possibly be used to model the cloud movement.

The most probable detonation in nuclear fuel cycle facilities is a "redoil" explosion. "Red oil" is formed when nitric acid solutions are accidentally heated with tributyl phosphate in an organic solvent. The "red oil" itself is nitrated tributyl phosphate possibly mixed with other nitrated organic compounds. When heated, the mixture can detonate.

Tables 3.6, 3.7, and 3.8 present data from Nichols (1960) on red oil explosions. Table 3.6 presents the heat of reaction of $100 \%$ tributyl phosphate and $10.7 \mathrm{M}$ nitric acid at various temperatures. The weight referred to as the heat of reaction (Btu/lb) is the weight of the nitrated organic phase. Table 3.7 is a series of correction factors for concentration effects to be used for other tributyl phosphate and nitric acid concentrations. For example, "red oil" prepared from 30\% tributyl phosphate and $4 \mathrm{M}$ nitric acid would have a correction factor of 0.20 . If the mixture is assumed to explode at $140^{\circ} \mathrm{C}$, the heat of reaction would be $(0.20)(367)=73.4 \mathrm{Btu} / \mathrm{lb}$ or $41 \mathrm{cal} / \mathrm{g}$. "Red oil" under these conditions would be about $4 \%$ as powerful an explosive as TNT. The maximum explosive power of "red oil" would be if a mixture formed from concentrated nitric acid and $100 \%$ TBP exploded at $160^{\circ} \mathrm{C}$. The explosion of 1 lb of "red oil" under these conditions would be equivalent to about 0.23 lb of TNT.

The effect of temperature upon the heat of reaction of "red oil" indicates that it may be desirable to estimate the actual temperature at which the

\section{TABLE 3.6. Heat of Reaction of Tributyl Phosphate (TBP) Nitration(a)}

Basis of $1,000 \mathrm{~g}$ of organic phase prepared by contacting one part of $100 \%$ TBP with five parts of $10.7 \mathrm{M} \mathrm{HNO}_{3}$

$\begin{array}{llllll}\text { Temperature }\left({ }^{\circ} \mathrm{C}\right) & 120 & 130 & 140 & 150 & 160 \\ \text { Heat of reaction (Btu/Ib) } & 319 & 331 & 367 & 418 & 464\end{array}$

(a) Excerpted from Nichols (1960). 

TABLE 3.7. Correction for Concentration of Nitrate in the Organic Phase
at Zero Time(a)

\begin{tabular}{|c|c|c|c|}
\hline \multirow{2}{*}{$\begin{array}{l}\mathrm{HNO}_{3} \text { Concen- } \\
\text { tration in } \\
\text { Aqueous Phase } \\
\text { (M) }\end{array}$} & \multicolumn{3}{|c|}{$\begin{array}{c}\text { Relative Concentration of } \\
\text { Original Reactant }\end{array}$} \\
\hline & $30 \%$ TBP & $50 \%$ TBP & $100 \%$ TBP \\
\hline 10.7 & -- & -- & 1.00 \\
\hline 10 & 0.38 & 0.59 & 0.99 \\
\hline 8 & 0.35 & 0.57 & 0.95 \\
\hline 6 & 0.28 & 0.49 & 0.86 \\
\hline 4 & 0.20 & 0.37 & 0.72 \\
\hline 2 & 0.10 & 0.20 & 0.45 \\
\hline
\end{tabular}

(a) Nichols (1960) TABLE 3.8. Coefficient of Rate Equation for Tributyl Phosphate
Nitrate Reaction

Coefficients of the Arrhenius Equation: $t_{1 / 2}=\frac{0.693}{s} e^{E / R T}$,

where

$$
\begin{aligned}
t_{1 / 2} & =\text { half }-1 \text { ife of reaction } \\
R & =\text { gas constant, cal } /(\mathrm{g}-\mathrm{mol})\left({ }^{\circ} \mathrm{K}\right) \\
T & =\text { temperature, }{ }^{\circ} \mathrm{K} \\
\mathrm{S} & =\text { frequency factor, } \mathrm{s}^{-1} \\
\mathrm{E} & =\text { activation energy, cal } /(\mathrm{g}-\mathrm{mol})\left({ }^{\circ} \mathrm{K}\right)
\end{aligned}
$$

Uranyl nitrate in aqueous phase $(M) \quad 0$

Nitric acid in aqueous phase (M)

$6-11 \quad 8.9 \quad 3.0$

Energy of activation $\left[\mathrm{cal} /(\mathrm{g}-\mathrm{mol})\left({ }^{\circ} \mathrm{K}\right)\right]$

$26,800 \quad 26,800 \quad 26,800$

Frequency factor $\times\left(\mathrm{s}^{-1}\right)$

$43 \times 10^{9} 24 \times 10^{9} 7.6 \times 10^{7}$

(a) Nichols (1960) 
reaction occurs. The calculation below is taken from Nichols (1960) and is based on a heat balance for the reactor vessel. The heat balance is expressed as :

Heat loss from reactor $=$ heat generated in reactor

$$
U A(T-t)=H C V \rho s e^{-E / R T}
$$

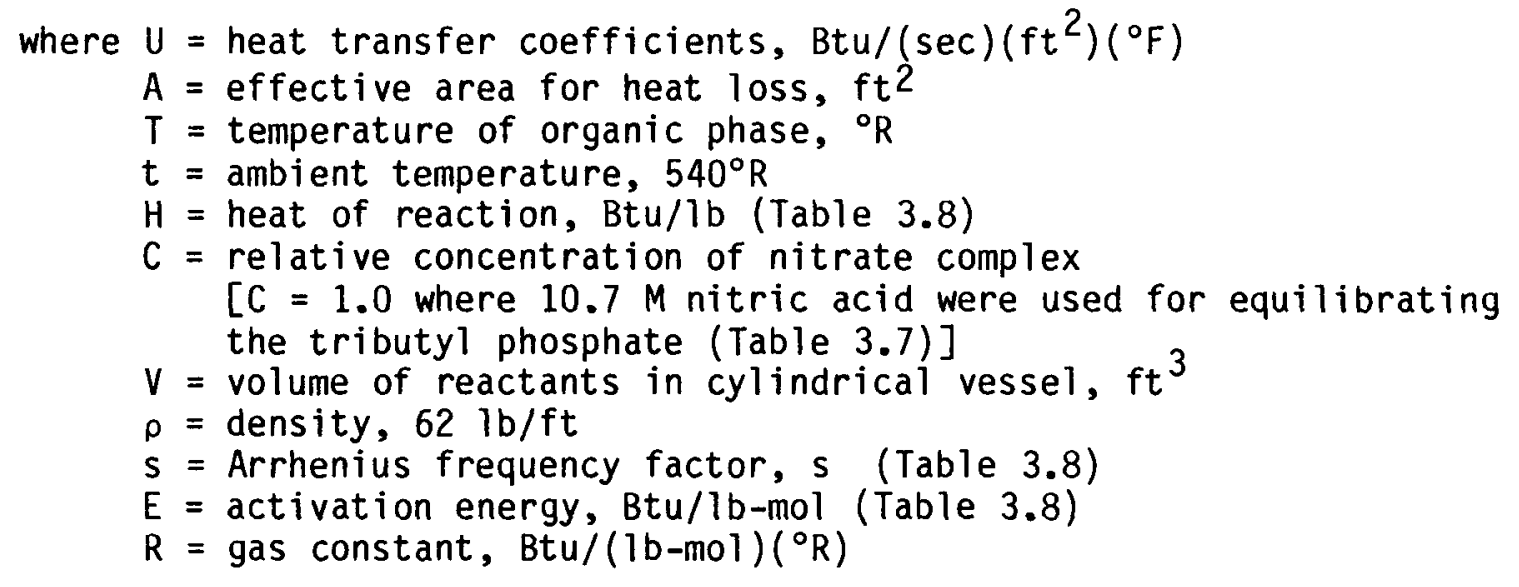

After the variables of geometry have been separated from those of temperature, the equation becomes:

$$
U A / V C=H s e^{-E / R T} / T-t
$$

Solving this equation for $T$, the initiation temperature, requires a knowledge of heat transfer coefficients and the effective area for heat loss. $U$, the heat transfer coefficient, can be estimated from any number of heat transfer correlations, depending on the geometry of the system. If the system is taken to be a pseudoequilibrium condition, the controlling resistance to heat transfer is probably the convective heat transfer coefficient to the atmosphere. For air in forced convection (as in a veptilated room), the heat transfer coefficient is typically 2 to $15 \mathrm{Btu} /(\mathrm{hr})\left(\mathrm{ft}^{2}\right)\left({ }^{\circ} \mathrm{F}\right)$ (Bennett and Myers 1974). For natural convection, the coefficient is typically 0.5 to $2 \mathrm{Btu} /(\mathrm{hr})\left(\mathrm{ft}^{2}\right)\left({ }^{\circ} \mathrm{F}\right)$. Better estimates can be made using standard heat transfer correlations.

The effective area for heat loss is essentially the external area of the vessel. Exceptions to this would include any insulated surfaces, or surfaces that are not in thermal equilibrium with the reactants. For example, if a large reactor contains only a small volume of reactants, the effective area for heat loss would be the surface area of the vessel adjacent to the reactants plus the free surface of the reactants. Not included in these calculations is the effect of any external heating or cooling in the reactant mass, including heating or cooling coils and external energy sources such as fires. In the case of coils, another term would be added to the heat balance. In the case of fires, the heat transfer coefficient would be calculated for transfer from the room to the vessel instead of from the vessel to the room. 
The final effect of a detonation is the rapid rush of wind associated with the blast. This is not the blast wave itself (the wave travels at the speed of sound), but a short-duration wind that follows the blast wave. Figure 3.2 shows the wind velocity $U$ (called the particle velocity on this figure) as a function of the scaled distance. This value is the maximum value of the wind speed. The wind speed decays to zero over the duration of the positive phase of the blast and eventually reverses direction (returns toward blast center) during the negative phase of the blast wave. The wind speed associated with the negative phase is much less than that of the positive phase because the associated pressure gradients are less.

The initial wind velocity can be related to the peak side-on overpressure in two ways. Gugan (1979) presents the results of Bowen et al. (1961) where the relationship $U_{S}=P_{S} /\left(1+P_{S} 1 / 2\right)$ is derived. Here $U_{S}$ is the Mach number of the particle velocity and $P_{S}$ is the peak side-on overpressure divided by the original atmospheric pressure. This result was based on earlier work by Brode (1955). Brode derived the equation

$$
U_{s}=\frac{5 \Delta P S}{\left(49+42 \Delta P_{s}\right)^{1 / 2}}
$$

based on the Hugoniot relationship. Here $U_{S}$ is still the Mach number and $\Delta P_{S}$ is the peak side-on overpressure expressed in atmospheres. If the original atmospheric pressure is taken as 1 atm, the $\Delta P_{S}$ and $P_{S}$ are equivalent numerically.

These equations were derived for the winds associated with the positive phase of the explosion. For the negative phase, substituting the peak side-on underpressure for the peak side-on overpressure in the above equations should yield a useable number.

The velocities calculated above decay exponentially with time. Gugan (1979) presents the results of Bowen et al. (1961). Bowen et al. modeled the decay as

$$
U=U_{S}(1-z) e^{-\nu z}
$$

where $U=$ wind speed Mach number at reduced time $z$

$$
\begin{aligned}
U_{S}= & \text { wind speed Mach number at } z=0 \\
Z= & \text { reduced time into the positive phase } \\
\nu= & \text { copstant that depends on the overpressure }\left(P_{S}\right), \\
& P 1 / 3+0.0032 P 3 / 2
\end{aligned}
$$

To use this equation properly, some knowledge of the duration of the positive phase must be available. Figure 3.2 presents graphs of both the positive and negative phase durations. Numerical modeling of these results is currently under way to provide a simple program to predict these durations.

Originally, we thought that the average wind speed and the wind duration could be used to predict entrainment of loose particles caused by the 
explosion-induced wind, although the situation is not so simple. The wind durations associated with a blast are on the order of $100 \mathrm{~ms}(0.1 \mathrm{sec})$, which is a very short time. Most experimental data on entrainment resulting from wind was gathered during long-term, steady-state experiments, and the transient, short-lived wind presents a different case. Three methods are known to us by which an entrainment source term resulting from a blast wave can be calculated. Each method uses various assumptions and has different limitations, and will be presented here with an attempt to compare the results for a "typical" accident scenario.

The first method is that of Martin et al. (1983). Their method, used in the TORAC code, is based on the work of Iversen et al. (1976). (The TORAC code is another transport code that was also developed by LANL.) In this method, experimental data of the particulate threshold friction speed were fitted by semi-empirical equations. The equations are:

$$
A=\left(0.108+0.0323 / B-0.00173 / B^{2}\right) \times\left(1+0.55 / \rho_{p} g D_{p}^{2}\right)^{1 / 2}
$$

$$
\text { where } \begin{aligned}
A & =u_{\star t} /\left[\left(\rho_{p}-\rho\right) g D_{p} / \rho\right]^{1 / 2} \\
B & =u_{\star t} D_{p} / \nu \\
D_{p} & =\text { average particle diameter } \\
\rho_{p} & =\text { particle density } \\
g & =\text { gravitational acceleration, } 980 \mathrm{~cm} / \mathrm{sec}^{2} \\
\nu & =\mu / \rho=\text { fluid kinematic viscosity }=0.1454 \mathrm{~cm}^{2} / \mathrm{sec} \text { for air }
\end{aligned}
$$

and

$$
A=0.266\left(1+0.55 / \rho_{p} g D_{p}^{2}\right)^{1 / 2} \times(1+2.123 B)^{-1.2}
$$

Equation (29) is valid for $0.22 \leq B \leq 10$ and Equation (30) is valid for $B<0.22$. The value of $u_{\star t}$, the threshold friction velocity, is then compared with $U_{*}$, the actual friction velocity at the entrainment surface. To estimate $U_{*}$, some estimate of the hydrodynamics of the situation must be used. Martin assumed fully developed flow in ducts with a moderately rough surface and a boundary-layer thickness of $10 \mathrm{~cm}$. These numbers result in the equation:

$$
u(y) / U_{\star}=1 / 0.4 \ln 10 / 0.0104=17.2
$$

\footnotetext{
where $\quad 10 \mathrm{~cm}=$ distance from surface

$0.4=$ von Karman constant

$0.0104 \mathrm{~cm}=$ roughness length

$u(y)=$ bulk velocity

$U_{*}=$ calculated friction velocity
} 
Both the boundary-layer thickness and the roughness can be varied to give different results. Entrainment is assumed to occur for all particles for which $u_{*}>u_{* t}$. The suspension flux of particles is estimated by

$$
q_{v}=q_{h}\left(c_{v} / u_{* t}^{3} c_{h}\right)\left[\left(u_{*} / u_{* t}\right)^{p / 3}-1\right]
$$

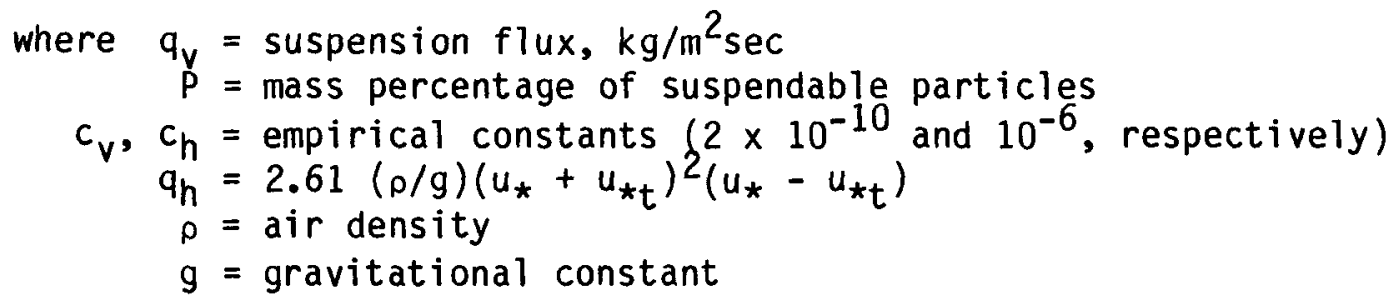

The source term is then

$\dot{m}_{p}=q_{v} A_{p}$, where $A_{p}$ is the duct area covered with powder.

Assuming there is a fully developed flow in a duct is justified in this transient case because the calculations are performed for small time steps. The EXPAC time step is about $10 \mathrm{~ms}$, which is adequate for using the above TORAC subroutines applied to transient explosion winds.

The method is applicable to one particle size at a time, which means that it would have to be applied several times to a nonuniform size distribution or distribution calculations would have to be added to existing codes. The method also assumes powder is spread uniformly over Area A in a "thick" bed, which may or may not be appropriate in all cases (as noted by Martin et al. (1983) in their own work).

The second method is that of IDCOR (1984). This method is considerably simpler because more assumptions have been built into this model. The final result of their calculations is that if the velocity of air over the powder $(u)$ is greater than $u_{\infty}$ as given below, entrainment occurs.

$$
u_{\infty} \geq 9.62 \frac{\nu}{D} \cdot\left(\frac{d}{\rho \nu^{2}}\right)^{0.4082} \cdot\left(\frac{D}{d}\right)^{8 / 7}
$$

where $\nu=$ kinematic viscosity of air $=0.1454 \mathrm{~cm}^{2} / \mathrm{sec}$

$\mathrm{d}=$ particle diameter, $\mathrm{cm}$

$\rho=$ particle density, $\mathrm{g} / \mathrm{cm}^{3}$

$D=$ duct diameter, $\mathrm{cm}$

Note that, as in the TORAC model, flow in ducts is assumed. Here the actual dimension of the duct, $D$, occurs to the $1 / 7$ power. The equation is relatively insensitive to $D$. The room height could be used as $D$ with little error. This equation also combines an empirical lower bound estimate of Corn's (1961) experimental data, the Blasius formula for the friction factor in parallel plate flow, and an expression for the gas velocity $U$ close to a well in 
terms of the friction factor and the bulk velocity. The equation also assumes that individual particles do not interact with one another. The effects of exposure time are not quantified, but the empirical expression of Corn's data is based on 1-min or greater exposure times. This model assumes therefore that the resuspension flux, $q_{u}$ (in the TORAC model) can be essentially $\infty$. Once again, all particles are assumed at a risk and a single particle size is used. Thin beds of particles are assumed.

The third and final method is that of singer et al. (1976). This is essentially a totally empirical model based on curve fits to a set of experimental data on the dispersion of coal and rock dusts. A rectangular pile of material is assumed, and particle size is not accounted for. Only the bulk density of the powder $\left(\rho_{B}\right)$, the height of the pile $(H)$, and the wind velocity $\left(U_{A}\right)$ are important. A series of five equations, based on both steady state wind tunnel tests and explosion tunnel experiments, are presented. These equations give the entrainment rate, $E\left(\mathrm{~g} / \mathrm{cm}\right.$ width-sec) in terms of $\rho_{B}, H$, and $U_{A}$. The equations are:

$$
\begin{aligned}
& E_{\text {PRED }}=13.6 \rho_{B}^{0.63} H^{0.84} U_{A}^{0.064} \\
& E_{\text {PRED }}=33.8 \rho_{B}^{1.16} H^{0.61} U_{A}^{0.35} \\
& E_{\text {PRED }}=13.8 \rho_{B}^{0.903} H^{0.75} U_{A}^{0.76} \\
& E_{\text {PRED }}=78.1 \rho_{B}^{0.675} H^{1.3} U_{A}^{0.40}
\end{aligned}
$$

Equation (34) is applicable to piles less than $5 \mathrm{~cm}$ long; Equation (35) is for piles between 5 and $10 \mathrm{~cm}$ long; Equation (36) is for piles between 10 and $15 \mathrm{~cm}$ long; and Equation (37) is for piles between 15 and $20 \mathrm{~cm}$ long. Note that for a 20-cm-1ong pile, Equations (37), (36), (35), and (34) would be used successively to calculate the entrainment rate. These models assume that the width of the pile facing into the blast is constant. Since the original experiments were done with $20-\mathrm{cm}$ piles, entrainment rates for longer piles were not estimated. The average entrainment rate for the entire $20-\mathrm{cm}$ pile was estimated as

$$
\bar{E}_{\text {PRED }}=15.0 \rho_{\mathrm{B}}^{0.93} \mathrm{H}^{0.74} \bar{V}_{\mathrm{A}}^{0.48}
$$

Using this average equation would probably be just as accurate for large piles as successively using Equations 34 through 37.

The method of Martin et al. (1983) as used in the TORAC code is the preferred method for our work. This method has probably the best theoretical basis and the most applicable experimental basis. Although the method is more complicated than the other two methods and does not lend itself well to hand 
calculations, the whole explosion process is complicated enough to require a computer model. We recommend that the particle entrainment subroutines in TORAC be included in EXPAC.

\subsection{SLOW CHEMICAL EXPLOSIONS}

Slow chemical explosions are typically called deflagrations. A deflagration is accompanied by a pressure pulse and transient wind much like a detonation, but the pressure pulse is not a shock front. A typical deflagration in a nuclear fuel cycle facility might be the ignition of a roomful of flammable gas and air. The gases might include methane or natural gas from gas-powered equipment or heating units, hydrogen from radiolysis of water or electric battery leakage, or unburned pyrolyzates from a fire.

Deflagrations are probably the most complicated and least understood of the four types of explosions. The most common method of modeling a deflagration involves assigning a TNT equivalent weight to the explosion cloud and using ideal point source blast wave theory. This method does not give very accurate results close to the explosion source, but accuracy increases with distance.

The first step in assigning a TNT equivalent weight is to estimate the mass of flammable gas involved in the deflagration. Usually, all gas or vapor that has leaked is considered to be at risk, although this may be untrue in the case of a very slow leak or very fast releases. During a slow leak, the gas has a chance to diffuse, and some of the gas may be sufficiently diluted to decrease its concentration to below the lower flammable limit. During a fast release, the concentration may be above the upper flammable limit. In either case, some portion of the gas would be unavailable for combustion, so it is conservative to assume that all the leaked gas is at risk. Additionally, the flammable gas-air mixture is usually considered to form a stoichiometric mixture. The heat of combustion of the mixture can be found from tabular combustion data or from bond energy calculations.

The next step in assigning a TNT equivalent weight to an explosion cloud is to calculate what fraction of the available combustion energy is actually consumed in a deflagration. Typically, a deflagration uses $10 \%$ or less of the available energy (Strehlow 1972). It is an extremely complicated process to predict how much of the energy in a deflagration is released as kinetic energy in a TNT-equivalent explosion. Gugan (1979) presents a derivation of an explosion efficiency evaluation for deflagrations that he admits is not exact and has many simplifying assumptions that may or may not be valid. His results give the efficiency as:

$$
\eta=1.94 \times 10^{-10} \frac{M^{1 / 3-2} \Delta H\left(M_{\nu} \varepsilon\right)^{2 / 3}}{R}
$$


where $\eta=$ explosion efficiency

$M=$ mass of flammable material, $\mathrm{kg}$

$\bar{\nu}=$ average flame speed, $\mathrm{m} / \mathrm{sec}$

$\Delta H=$ heat release per unit mass flammable material, joules $/ \mathrm{kg}$

$M_{v}=$ molecular weight of flammable gas, $\mathrm{kg} / \mathrm{kg} \mathrm{mol}$

$\varepsilon=$ stoichiometric volume ratio, mols of flammable gas $/ \mathrm{mols}$ of flammable gas and air

$R=$ distance from the source, $m$

Note that the apparent efficiency of the deflagration depends on the distance, $\mathrm{R}$, from the source. This dependency has been noted elsewhere (Strehlow 1972).Strehlow also notes that deflagrations typically give slower pressure rises, lower total overpressures, and longer positive phase durations than one would expect from an equivalent ideal blast. The longer positive phase duration could be significant if the resuspension effects mentioned in the section on fast chemical explosions are important. Johannsohn (1976) reports overpressure durations for fuel-air explosions that are twice that of an equivalent conventional explosion.

Obviously, the use of ideal point-source blast wave theory leaves much to be desired for this case. Unfortunately, there is nothing available that is more applicable. A large-scale vapor cloud is definitely not a point source, and the energy release in a deflagration is not necessarily as rapid as a detonation.

Many other studies have pointed out other anomalies in gas phase deflagrations and detonations. A deflagration may accelerate into a detonation in some cases (only for certain geometries and for certain highly explosive gases such as methane or hydrogen). A deflagration or detonation may also exhibit highly directionally dependent properties. A great deal of information and data must be obtained before a mechanistic solution to the problem of slow chemical explosions can be formulated. 


\subsection{MODELING OF PNL EXPERIMENTAL RESULTS}

Pacific Northwest Laboratory has been performing experiments for the NRC since 1979 in the area of nuclear fuel cycle facility safety analysis. Two major series of experiments that are related to an explosion source term involved free-fall spills and pressurized releases. Results of these experiments have been published (Sutter, Johnston and Mishima 1981; Sutter 1983), but complete analysis of the results and additional experiments are not yet complete.

The results of these experiments, when plotted as weight percent of source airborne versus source energy per unit source mass, yielded what appeared to be a series of straight (or reasonably straight) lines (Figure 4.1). It was hoped that further consideration of the data would collapse the data into a single line or curve, based on an assumption that the energy input into a source material should be in some way related to the overall amount of material made airborne. Obviously, the energy release mechanisms are quite different in spills, pressurized releases, and explosions, but it was hoped that some fundamental process might be occurring. It was felt that the important parameters were probably source mass, source energy, and the bulk density of the source material. We attempted to model the influence of the bulk density of source material. Linear regressions of the data were made of the experimental data in the forms of wt\% airborne versus $E / M_{0}, E_{\rho} / M_{0}$, and $E / M_{\rho} \rho$, where $E$ = source energy, $\rho=$ bulk density, and $M_{0}=$ source mass. Neither of the attempted density corrections made much of an improvement in the regressions of the data. Higher order density corrections ( $p^{2}$, etc.) were considered, but did not appear useful. As can be seen in Figure 4.1, there is considerable spread in the data even for supposedly identical runs, which indicates that some factor or factors beyond our control is influencing the results. It is possible that the wt\% airborne versus $E / M_{0}$ correlation is the best we can reasonably expect. Other possible factors controlling the dispersion of powders might be air humidity with its influence on powder cohesion and degree of caking of the powder in the pressurized release chamber. Factors involved in the dispersion of liquids might include source temperature with its effect on surface tension and humidity, and temperature of the aerosol release tank with its effects on droplet evaporation. Unfortunately none of the parameters were measured consistently and several of them are probably nearly impossible to measure.

Figure 4.1 also shows the line resulting from our curve fit of the data from Steindler and Seefeldt (1980). Note that the powder pressurized releases fall above the line, while the liquid pressurized releases fall mainly below the line. The Steindler-Seefeldt model is based on experimental data involving explosive dissemination of liquids and solids, and on the assumption that some unit energy input into the source material will give a unit amount of surface area. The Steindler-Seefeldt model is also based on mass ratio (MR), the ratio of the weight of inert material in grams to the weight (or equivalent weight) of TNT in grams. Figure 4.1 is based on $E / M_{0}$, which is related to the recriprocal of the mass ratio. The relationship is 


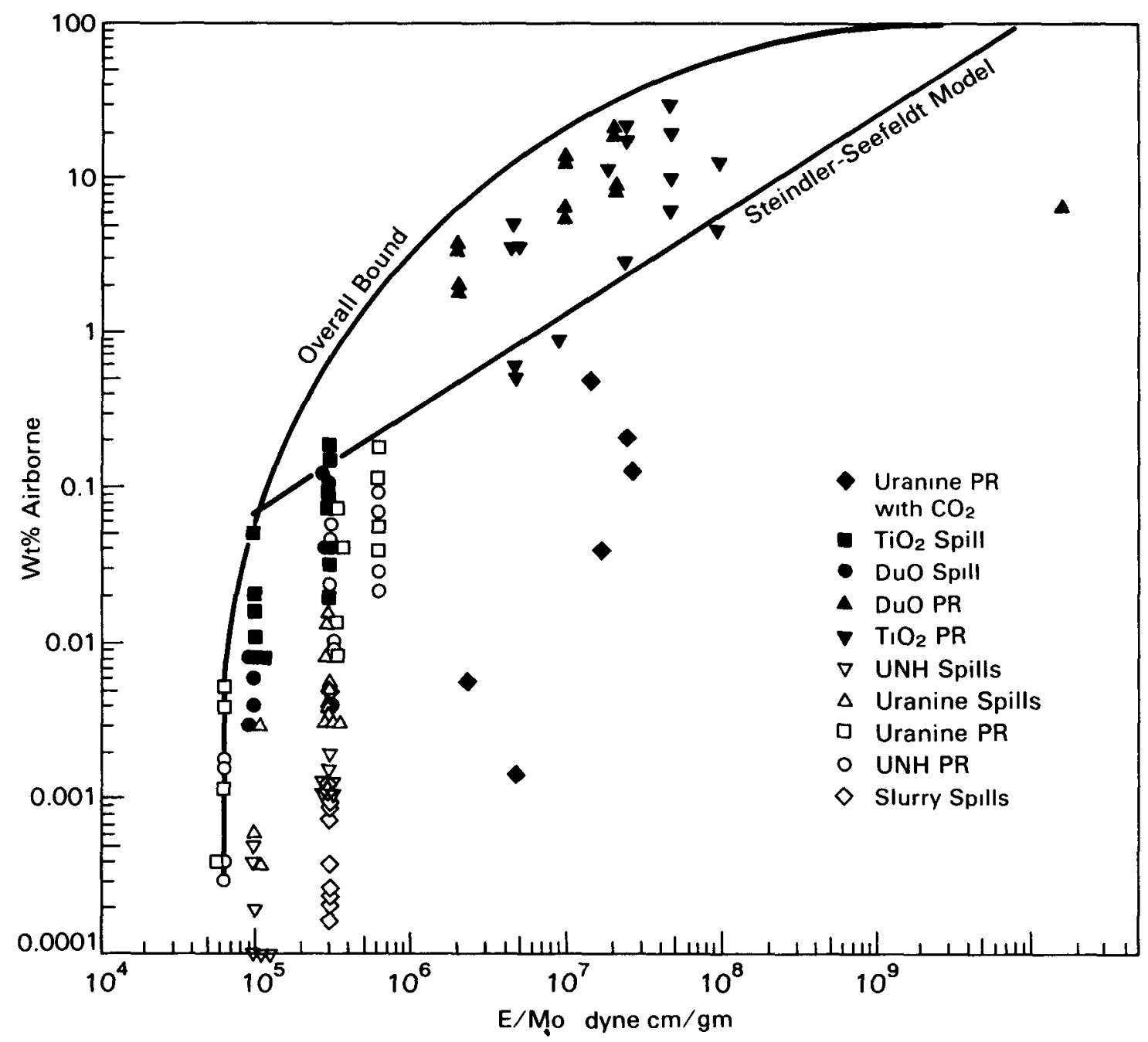

FIGURE 4.1. PNL Experimental Results, and Curve Fits

$$
\left(E / M_{0}\right)\left(\frac{\text { dyne } c m}{g}\right)=\frac{4.2 \times 10^{10}}{M R}
$$

where $E=$ source energy

$$
M_{0}=\text { weight of inert material }
$$

Table 4.1 presents some examples of calculated mass ratios and $E / M_{0}$ for various combinations of inert material and explosives.

Since only a finite amount of energy was released in the source material, any energy used to create surface area is not available to disperse the material. In the case of powders, surface area creation is negligible and a larger 
TABLE 4.1. Mass Ratio and E/Mo Examples

\begin{tabular}{|c|c|c|c|}
\hline $\begin{array}{c}\text { Amount of } \\
\text { Explosive }(g)\end{array}$ & $\begin{array}{c}\text { Amount of } \\
\text { Inert Material (g) }\end{array}$ & $\begin{array}{l}\text { Mass } \\
\text { Ratio } \\
\end{array}$ & $\begin{array}{r}E / M_{g} \\
\text { dyne-cm } / g\end{array}$ \\
\hline 1 & 1 & 1 & $4.2 \times 10^{10}$ \\
\hline 1 & 10 & 10 & $4.2 \times 10^{9}$ \\
\hline 1 & 100 & 100 & $4.2 \times 10^{8}$ \\
\hline 1 & 1000 & 1000 & $4.2 \times 10^{7}$ \\
\hline 1 & 10,000 & 10,000 & $4.2 \times 10^{6}$ \\
\hline 1 & 100,000 & 100,000 & $4.2 \times 10^{5}$ \\
\hline 1 & $1,000,000$ & $1,000,000$ & $4.2 \times 10^{4}$ \\
\hline
\end{tabular}

part of source energy can be used to disperse material. This leads to the higher weight percent airborne seen for powders.

The fact that the Steindler-Seefeldt model seems to be an upper bound for the liquid pressurized releases may indicate that our dispersion of liquids is not as efficient as a chemical explosion, or it may be an artifact of the original derivation of the Steindler-Seefeldt model. The energy to source mass ratios in this range are at the extreme end of the Steindler-Seefeldt correlation and need further verification. The value of 10 dyne $\mathrm{cm} / \mathrm{g}$ corresponds to a mass ratio of 4000 in the Steindler-Seefeldt model. The value of $10^{8}$ dyne $\mathrm{cm} / \mathrm{g} \quad(M R=400)$ is at the low end of values discussed by Steindler and Seefeldt.

As an alternative to our attempted linear models, we have developed an upper bound expression for our experimental results. This model has no theoretical basis and is based solely on the author's perception of the data. A useful feature of the expression is that it can be easily put into a computer code to give conservative solutions. An equation that can be used is

$$
\log (w t \% \text { airborne })=-2.6+\sqrt{18.8\left(\log \frac{E}{M_{0}}\right)-\left(\log \frac{E}{M_{0}}\right)^{2}-67.2}
$$

where $\frac{E}{M_{0}}$ is expressed in dyne $-\mathrm{cm} / \mathrm{g}$.

The $E$ used in this expression is the energy applied for the deagglomeration and dispersion or subdivision and dispersion of the material. For venting pressurized powders, the total pressure is applicable. For venting liquids, the total pressure is not applicable and the gases dissolved in the liquid under the pressurization conditions are used. For the free-fall spill of powders or liquids, the energy from the attraction of gravity upon the material is applied. This equation is shown on Figure 4.1 as a circular arc centered at the point $\left(2.5 \times 10^{9}, 0.0025\right)$ and with a radiys of $4.6 \log$ units. Note that $100 \mathrm{wt} \%$ airborne is reached at $E / M_{0}=2.5 \times 10^{9}$, so no more material is released at higher 
$E / M_{0}$. Also note that little material is released below $E / M_{0}=6 \times 10^{4}$. The line shown on Figure 4.1 shows a maximum release of $0.0025 \%$ at $E / M_{0}=6 \times 10^{4}$. The shape of the upper-bound 1 jne below this point is unknown. By drawing a vertical line at $E / M_{0}=6 \times 10^{4}$, we have assumed that essentially no release occurs at $E / M_{0}<6 \times 10^{4}$.

The best line that can be drawn through all the data points is given by Equation 42:

$$
\text { wt\% airborne }=1.81 \times 10^{-9}\left(\frac{E}{M_{0}}\right)^{1.28}
$$

This equation is based on a linear regression of the $\log$ of the weight percent airborne versus the $\log$ of $E / M_{Q^{\circ}}$. The regression coefficient $\left(R^{2}\right)$ is 0.63 , indicating that the points follow a general trend rather than falling on a straight line. Because of the wide scatter of points on the graph, great care should be exercised in the use of this equation. 


\subsection{REFERENCES}

Abramowitz, M., and I. A. Stegun. 1965. Handbook of Mathematical Functions. National Bureau of Standards, Washington, D.C.

Alexander, J. M. 1981. Strengths of Materials. Ellis Horwood Limited, Chichester, England.

Baker, N. E., et al. 1983. Explosive Hazards and Evaluation. Elsevier Press, New York, New York.

Barsom, J. M., and S. T. Rolfe. 1970. "Fatigue and Burst Pressure of HY-140(T) Steel Pressure Vessels." Journal of Engineering for Industry, Transactions of the American Society of Mechanical Engineers. 92 (Series B, No. 1):11-22.

Bennett, C. 0., and J. E. Myers. 1974. Momentum, Heat and Mass Transfer. McGraw-Hill Co., New York, New York.

Bickell, M. B., and C. Ruiz. 1967. Pressure Vessel Design and Analysis. St. Martin's Press, New York.

Bird, R. B., W. E. Stewart, and E. N. Lightfoot. 1960. Transport Phenomena. John Wiley and Sons, New York, New York.

Brode, H. L. 1955. "Numerical Solutions of Spherical Blast Waves." Journal of Applied Physics. 26(6):766-775.

Brown, J., and J. L. York. 1962. "Sprays Formed by Flashing Liquid Jets." American Institute of Chemical Engineers Journal. 8(2):149-153.

Corn, M., and F. Stein. 1965. "Re-entrainment of Particles from a Plane Surface." American Industrial Hygiene Association Journal. 26:325.

Corn, J. 1961. "The Adhesion of Solid Particles to Solid Surfaces, A Review." Journal of the Air Pollution Control Association. 11:523.

Department of the Army, Navy, and Air Force. 1969. Structures to Resist the Effects of Accidental Explosions. TM 5-3100, NAVFAC P-397, AFM 88-22. Government Printing Office, Washington, D.C.

ERDA. 1976. Investigation of the Chemical Explosion of an Ion Exchange Resin Column and Resulting Americium Contamination of Personnel in the 242-2 Building, August 30, 1976. Energy Research and Development Administration, Richland Operations office, Richland, Washington.

Grelecki, C. A. 1972. Fundamentals of Fire and Explosion Hazards Evaluation. AIChE Today Series, American Institute of Chemical Engineers, New York, New York. 
Grelecki, C. A. 1976. "Investigation of Incident in Ion Exchange Resin." Appendix A of Explosion of Cation Exchange Column in Americium Recovery Service, Hanford Plant, August 30, 1976. HRC Report 3719, Atlantic Richfield Hanford Company, Richland, Washington.

Gugan, K. 1979. Unconfined Vapor Cloud Explosions. Gulf Publishing Company, Houston, Texas.

Higdon, A., E. H. Ohlsen, W. B. Stiles, and J. A. Weese. 1967. Mechanics of Materials. John Wiley and Sons, New York, New York.

Hutcherson, M. N., et al. 1984. Potential for Overpressurization of West Valley Liquid Fed Ceramic Melter by a Hypothetical Molten Salt/Aqueous Phase Vapor Explosion. FAI/84-43, Fauske and Associates, Inc., Burr Ridge, Illinois.

IDCOR. 1984. Technical Report: Resuspension of Deposited Aerosols Following Primary System or Containment Failure. Draft, Industry Degraded Core Rulemalcing Program, Atomic Industrial Forum, Bethesda, Maryland.

Iversen, J. D., et al. 1976. "Saltation Threshold on Mars: The Effect of Interparticle Force, Surface Roughness, and Low Atmospheric Density." ICARUS. 29:381-393.

Iversen, J. D., R. Greeley, and J. B. Pollack. 1976. "Windblown Dust on Earth, Mars, and Venus." Journal of Atmospheric Science. $33(12): 2425-2429$.

Jenkins, C. E., E. S. Murphy, and K. J. Schneider. 1979. Technology, Safety and Costs of Decommissioning a Reference Small Mixed 0xide Fuel Fabrication Plant. NUREG/CR-0129, Vol. I and II, U.S. Nuclear Regulatory Commission, Washington, D.C.

Lee, J. H., et al. 1977. "Blast Effects from Vapor Cloud Explosions." Paper presented at the Eleventh Loss Prevention Symposium, American Institute of Chemical Engineers, March 21-29, 1977, Houston, Texas.

Marin, J., and J. A. Sauer. 1954. Strength of Materials. 2nd ed. The MacMillan Company, New York.

Martin, R. A., et al. 1983. Material Transport Analysis for Accident-Induced Flow in Nuclear Facilities. NUREG/CR-3527, U.S. Nuclear Regulatory Commission, Washington, D.C.

Nichols, G. S. 1960. Decomposition of the Tributyl Phosphate-Nitrate Complexes. DP-526, DuPont - Savannah River Project, Savannah River, Georgia.

Oston, S. G. 1981. Modification of Gaussian Diffusion Model to Accommodate an Explosive Event. The Analytical Sciences Corporation, Reading, Massachusetts. 
Owczarski, P. C. 1981. "Adiabatic Mixing of $\mathrm{NH}_{3}$ (Liquid) and Air." Appendix $B$ of Assessment of Research and Development (R\&D) Needs in Ammonia Safety and Environmental Control. PNL-4006, Pacific Northwest Laboratory, Richland, Washington.

Perry, R. H., D. W. Green, and J. 0. Maloney. 1984. Perry's Chemical Engineers' Handbook. 6th ed. McGraw-Hill Book Company, New York, New York.

Pohto, H. A. 1979. "Energy Releases from Rupturing High-Pressure Vessels: A Possible Code Consideration." Journal of Pressure Vessel Technology. $101: 165-170$.

Postma, A. K., C. C. Chapman, and J. L. Buelt. 1980. An Assessment of Water/ Glass Interactions in Waste Glass Melter Operation. PNL-2622, Pacific Northwest Laboratory, Richland, Washington.

Royer, C. P., S. T. Rolfe, and J. T. Easley. 1973. "Effect of Strain Hardening on Bursting Behavior of Pressure Vessels." Presented at the Second International Conference on Pressure Vessel Technology, Part II-Materials, Fabrication, and Inspection, October 1-4, 1973, San Antonio, Texas.

Sehmel, G. A. 1980. "Particle Resuspension: A Review." Environment International. $4: 107-127$.

Schneider, K. J., et al. 1982. Nuclear Fuel Cycle Risk Assessment: Descriptions of Representative Non-Reactor Facilities. NUREG/CR-2873, U.S. Nuclear Regulatory Commission, Washington, D.C.

Schneider, K. J. and C. E. Jenkins. 1977. Technology, Safety and Costs of Decommissioning a Reference Nuclear Fuel Reprocessing Plant. NUREG/CR-0278, Volumes I and II, U.S. Nuclear Regulatory Commission. Washington, D.C.

Singer, J. M., M. E. Harris, and J. Grumer. 1976. Dust Dispersal by Explosion-Induced Air Flow: Entrainment by Air Blast. BuMines RI 8130, Bureau of Mines, U.S. Department of the Interior, Pittsburgh, Pennsylvania.

Smith, R. I., G. J. Konzak, and W. E. Kennedy, Jr. 1978. Technology, Safety and Costs of Decommissioning a Reference Pressurized Water Reactor Power Station. NUREG/CR-0130, Volumes I and II, U.S. Nuclear Regulatory Commission. Wastington, D.C.

Steindler, M. J. and W. B. Seefeldt. 1980. "A Method for Estimating the Challenge to an Air Cleaning System Resulting from an Accidental Explosive Event." In Proceedings of the 16th DOE Nuclear Air Cleaning Conference, ed. M. W. First, pp. 1165-1174. Harvard Air Cleaning Laboratory, Boston, Massachusetts. 
Strehlow, R. A. 1972. "Unconfined Vapor Cloud Explosions - An Overview." In Proceedings of Fourteenth Symposium (International) on Combustion, ed. R. S. Chaiken, pp. 1189-1200. Combustion Institute, Pittsburgh, Pennsylvania.

Sutter, S. L. 1983. Aerosol Generated by Releases of Pressurized Powders and Solutions in Static Air. NUREG/CR-3093, U.S. Nuclear Regulatory Commission, Washington, D.C.

Sutter, S. L., J. W. Johnston, and J. Mishima. 1981. Aerosols Generated by Free Fall Spills of Powders and Solutions in Static Air. NUREG/CR-2139, U.S. Nuclear Regulatory Commission, Washington, D.C. 


\section{DISTRIBUTION}

No. of

Copies

OFFSITE

L. C. Rouse

U.S. Nuclear Regulatory

Commission

Office of Nuclear Material

Safety and Safeguards, Divi-

sion of Fuel Cycle and

Material Safety

Advanced Fuel and Spent Fuel

Licensing Branch

Mail Stop 396-SS

Washington, D.C. 80555

10 J. E. Ayer

U.S. Nuclear Regulatory Commission

Office of Nuclear Material Safety and Safeguards, Division of Fuel Cycle and Material Safety

Advanced Fuel and Spent Fuel Licensing Branch

Mail Stop 396-SS

Washington, D.C. 80555

A. T. Clark

U.S. Nuclear Regulatory Commission

Office of Nuclear Material

Safety and Safeguards, Division of Fuel Cycle and Material Safety

Advanced Fuel and Spent Fuel Licensing Branch

Mail Stop 396-SS

Washington, D.C. 80555
No. of

Copies

P. Loysen

U.S. Nuclear Regulatory Commission

Office of Nuclear Material Safety and Safeguards, Division of Fuel Cycle and Material Safety

Advanced Fuel and Spent Fuel Licensing Branch

Mail Stop 396-SS

Washington, D.C. 80555

U.S. Nuclear Regulatory Commission

Office of Nuclear Reactor Regulation

Division of Systems Integration

Accident Evaluation Branch

Mail Stop P-802

Washington, D.C. 20555

U.S. Nuclear Regulatory Commission

Division of Technical Information and Document Control

7920 Norfolk Avenue

Bethesda, MD 20014

W. S. Gregory

Los Alamos National Laboratory

P. 0. Box 1663

Los Alamos, NM 87545

B. D. Nichols

Los Alamos National Laboratory

P. 0. Box 1663

Los Alamos, NM 87545 
No. of

Copies

M. Simen-Tov

Martin Marietta Energy Systems, Inc.

Oak Ridge National Laboratory

Process Engineering

P. 0. Box $X$

Oak Ridge, Tennessee 37831

W. R. Williams

Martin Marietta Energy Systems, Inc.

Oak Ridge National Laboratory

Process Engineering

P. 0. Box X

Oak Ridge, Tennessee 37831
No. of

Copies

ONSITE

45 Pacific Northwest Laboratory

M. Y. Ballinger

K. A. Borgeson

D. W. Dragnich

C. E. Elderkin

J. J. Fuquay

J. M. Hales

M. A. Halverson (20)

P. C. Hays

N. S. Laulainen

J. Mishima (2)

P. C. Owczarski (5)

J. A. Stottlemyre

R. E. Wildung

R. K. Woodruff

Publishing Coordination (2)

Technical Information (5) 


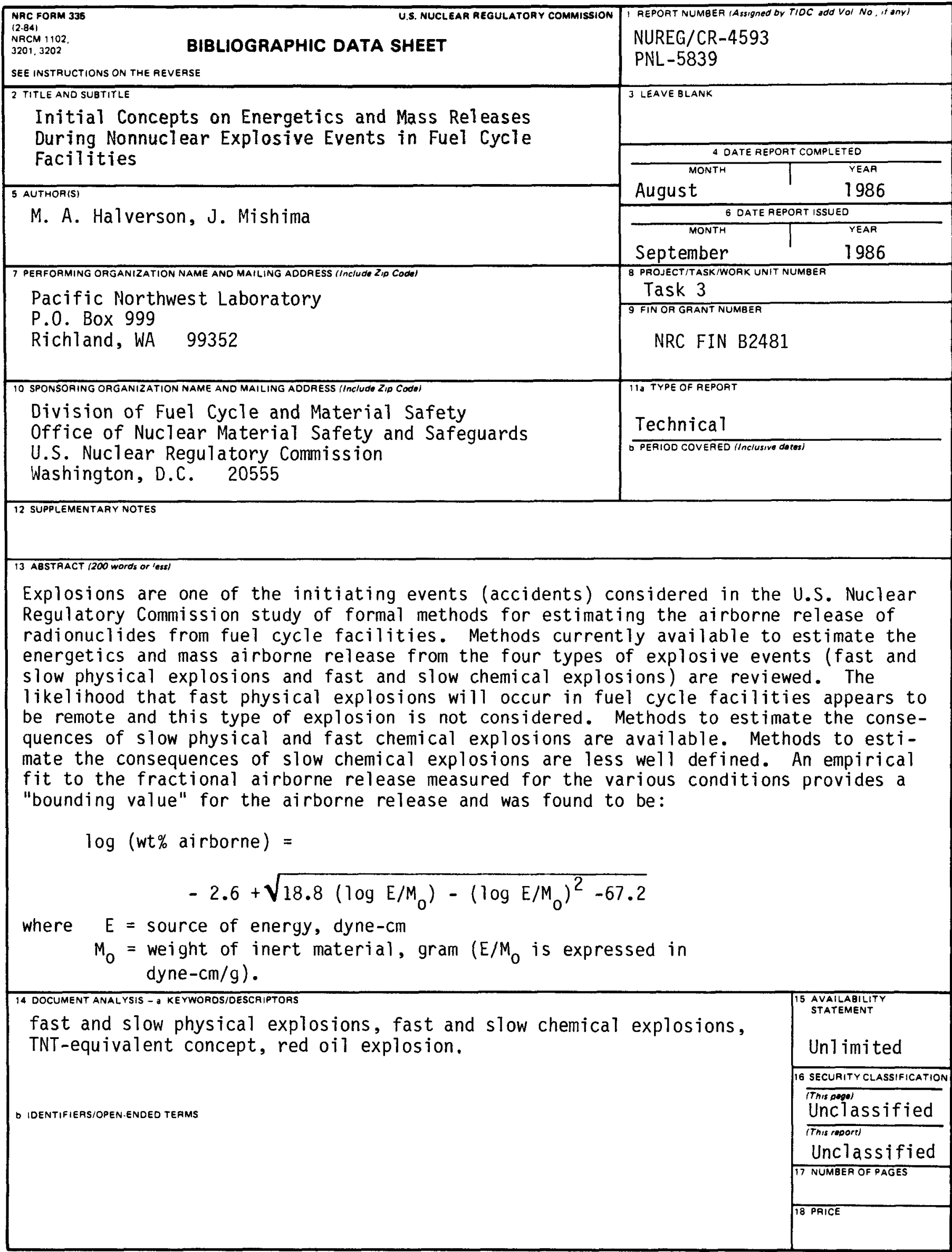

